\title{
ŚRODOWISKO PRZYRODNICZE WSPÓŁCZESNYM PROBLEMEM NIE TYLKO NAUK PEDAGOGICZNYCH, ALE I PEDAGOGIKI PRACY, WŁĄCZNIE Z NAUKAMI O PRACY
}

\begin{abstract}
Streszczenie: Dotychczas mało doceniane, wręcz niedostrzegane przez większość nauk o pracy, w tym przez pedagogikę pracy, środowisko przyrodnicze obecnie przeżywa renesans. Poszukuje się przyjaźniejszych mu metod pracy, powszechniej stosuje niekonwencjonalne systemy grzewcze, nie tylko w działalności gospodarczej, ale i w gospodarstwach domowych. Wreszcie odchodzi się od opakowań i wytworów niebiodegradowalnych na rzecz ulegających biodegradacji w krótkim czasie. Owe założenia kierują się w stronę pracy i życia człowieka oraz wynikają z potrzeby uczynienia ich przyjaznymi środowisku przyrodniczemu. Zadania te wpisują się w działania kilku dyscyplin wiedzy, w tym pedagogicznych i nauk o pracy, rozpatrujących pracę z wielu punktów widzenia i starających się na tej podstawie ukazać oczekiwania wobec przyrody, w tym samej pracy oraz pracującego i żyjącego w środowisku przyrodniczym człowieka.
\end{abstract}

Słowa kluczowe: środowisko, środowisko naturalne, środowisko przyrodnicze, człowiek, praca, pedagogika pracy, nauki o pracy, świadomość, świadomość ekologiczna (prośrodowiskowa), kształtowanie świadomości ekologicznej (prośrodowiskowej)

\section{Wstęp}

Dotychczas mało doceniana albo wręcz niedostrzegana przez większość nauk o pracy, a także pedagogicznych (w tym przez pedagogikę pracy) problematyka środowiska przyrodniczego obecnie przeżywa renesans. Wyraża się on w poszukiwaniu metod i technologii pracy bardziej przyjaznych środowisku przyrodniczemu, w powszechniejszym stosowaniu niekonwencjonalnych systemów grzewczych, nie tylko w działalności gospodarczej, ale i w gospodarstwach domowych, rezygnacji z używania opakowań i wytworów niebiodegradowalnych na rzecz ulegających biodegradacji i to w krótkim czasie. Tendencje te generują wyzwania wobec współczesnej pracy i potrzebę uczynienia jej przyjazną środowisku, a także 
kształtowania postaw prośrodowiskowych wyrażonych wysoką świadomością ekologiczną społeczeństwa. Zadanie to wpisuje się w działania wielu dyscyplin wie$\mathrm{dzy}$, rozpatrujących pracę z interesujących je punktów widzenia. Upowszechniają one wskazówki i rozwiązania dotyczące samego środowiska pracy, zatrudnionego w nim człowieka, a także procesu edukacyjnego obejmującego m.in. kwestie stosunku do przyrody, potrzebę organizacji pracy przyjaznej środowisku czy ograniczania odpadów z wielorakiej działalności człowieka oraz ich właściwego zagospodarowywania. Działania te powinny umożliwić przygotowanie człowieka do życia i pracy w symbiozie ze środowiskiem przyrodniczym. Dlatego zasadne jest spojrzenie na problematykę badawczą nauk o pracy oraz pedagogicznych, ze szczególnym podkreśleniem pedagogiki pracy z poradnictwem zawodowym (Nowacki 1972, 1973, 2004) oraz ich relacji z pedagogiką ekologiczną (Okoń 1992), pod kątem kształtowania postaw i zachowań przyjaznych wobec środowiska m.in. uczniów w szkołach, pracowników w pracy zawodowej, a także obywateli w domu oraz podczas wypoczynku, ukierunkowanych na chronienie, a tym samym przetrwanie i pozostawienie zasobów przyrodniczych w stanie co najmniej obecnym dla kolejnych pokoleń.

\section{Pedagogika pracy wobec kwestii ochrony środowiska przyrodniczego}

Pedagogika pracy, uznana w 1972 roku za samodzielną subdyscyplinę pedagogiczną (Nowacki 1972, 1973), wciąż dynamicznie się rozwija, o czym świadczy wzrastająca liczba pracowników naukowych specjalizujących się w tym zakresie, a także bardzo liczne publikacje, konferencje i seminaria naukowe poświęcone tej problematyce. Wspomnieć tu należy również o powołanych w ostatniej dekadzie w wielu ośrodkach akademickich kraju zakładach lub katedrach pedagogiki pracy (Baraniak 2015a, 2015b; Bednarczyk 2002).

Wzrastający dorobek tej subdyscypliny to wyraz zainteresowania teoretyków i praktyków przedmiotem badań wyznaczonym relacjami: człowiek - wychowanie - praca oraz rozbudowanych innymi konstelacjami, takimi jak: człowiek obywatel - pracownik, szkoła - życie - praca czy szkoła - zawód - praca. Niestety, dotychczas dorobek ten nie czynił z zagadnień środowiska przyrodniczego - poza inicjatywami ze strony jej twórcy (Nowacki 2004, s. 192; Nowacki 2008, s. 106; Nowacki, Jeruszka 2004, s. 31) - przedmiotu badań pedagogiki pracy. Nie inicjowano na ten temat zbyt wielu dyskusji, pomimo że problem zagrożenia dla stanu środowiska przyrodniczego był $\mathrm{i}$ jest dość dobrze znany i akcentowany przez różne światowe autorytety, m.in. przez wszystkich papieży ostatniego półwiecza (Jana XXIII, Pawła VI oraz Jana Pawła II). Na ich stanowiska powołuje się także obecny papież Franciszek w swojej encyklice Laudato si' z 2015 roku. Wydaje się zatem, że już najwyższy czas, aby subdyscyplina pedagogiczna, jaką jest pedagogika pracy, do swego obszaru badawczego włączyła również środowisko przyrodnicze, w którym żyje, uczy się, pracuje i odpoczywa człowiek. On bowiem, jako podmiot pracy, 
inicjuje wszelkie zmiany w procesie jej przebiegu, organizacji oraz kierunkach swego rozwoju zawodowego. Ludzie pracujący, w sposób pośredni, wpływają na zakres zainteresowań samej pedagogiki pracy problemami ochrony środowiska. $\mathrm{W}$ ten sposób jest szansa, że człowiek w procesie pracy będzie dążył, aby była ona jak najmniej uciążliwa dla otoczenia. Realizacji idei tak rozumianej pracy musi towarzyszyć kształtowanie wysokiej świadomości człowieka na temat wartości przyrody i potrzeby jej chronienia. Niezbędne do tego są odpowiednie programy wychowawcze, kierowane do wszystkich uczących się, tj. objętych zarówno edukacją przedzawodową, z dziećmi wieku przedszkolnego włącznie, poprzez uczniów szkół podstawowych, całą młodzież uczącą się na poziomie średnim w szkolnictwie ogólnokształcącym, jak i zawodowym, po pracujące osoby dorosłe uczestniczące w edukacji postzawodowej, czyli pracowników i pracodawców. Nie można też pominąć pozostałych obywateli, prowadzących np. gospodarstwa domowe, których stan wiedzy o ochronie środowiska powinny wzbogacać prelekcje proponowane np. przez jednostki samorządowe i inne lokalne organizacje. Potrzeba zwiększenia zainteresowania społeczeństwa treściami prośrodowiskowymi to ważny element kształtowania zachowań i postaw przyjaznych środowisku przyrodniczemu. Ich rozwój powinien w najbliższym czasie wzbogacić pole badawcze i teorie pedagogiki. Dlatego nauki pedagogiczne i nauki o pracy nie mogą dalej pomijać problemów dotyczących środowiska przyrodniczego, ale powinny włączyć je na trwałe w zakres swych zainteresowań, co pozwoli na lepsze kształtowanie świadomości proekologicznej społeczeństwa i budowanie jej w holistycznych modelach, nie tylko na gruncie pedagogiki pracy.

\section{Prośrodowiskowy charakter pedagogiki pracy}

Rozważania nad prośrodowiskowymi wymiarami pedagogiki pracy wiodą do ukazania istoty pedagogiki ekologicznej, której zręby odnajdujemy m.in. w poglądach Wincentego Okonia (1992, s. 152) oraz Tadeusza W. Nowackiego (2004, s. 192; por. Nowacki i in. 2000, s. 180). Wspólnym wątkiem obu koncepcji są problemy wychowania proekologicznego. Tadeusz W. Nowacki już w 1964 roku w swym dziele Wychowanie a cywilizacja techniczna ukazał je w aspekcie zmian środowiskowych, będących pokłosiem negatywnych działań ludzkich w przemyśle i rolnictwie, a także $\mathrm{w}$ innych dziedzinach gospodarowania. Już wówczas uważał, że problem ten nie powinien być dłużej pomijany, ale trzeba go wręcz eksponować zarówno $\mathrm{w}$ teorii pedagogiki pracy, jak i naukach o pracy. W pierwszym przypadku pomocne okazują się zaprojektowane blisko pół wieku temu, ale ciągle aktualne, czyli uniwersalne, obszary problemowe pedagogiki pracy (Nowacki 1972, 1978). Są one nie tylko wciąż cytowane, ale stanowią punkt wyjścia większości podejmowanych w pedagogice pracy badań. Nie mogą jednak nadal obejmować wyłącznie aspektów i kontekstów natury techniczno-organizacyjnej i ekonomicznej pracy, ale powinny wreszcie zostać poszerzone o problematykę środowiska przyrodniczego i projekcje 
właściwego wychowania, uwrażliwionego na kwestie zagrożeń ekologicznych. Współczesny człowiek musi mieć świadomość konieczności ochrony środowiska naturalnego; nie może godzić się na jego dalsze dewastowanie w wyniku stosowania nieprzyjaznych technologii, nadmiernej emisji spalin do otoczenia, a także rabunkowej eksploatacji złóż czy nienależytego zagospodarowywania odpadów, powstających w wyniku różnej działalności, w tym - pracy, w szczególności zawodowej. Spójrzmy zatem na treść każdego z obszarów badawczych pedagogiki pracy w aspekcie prośrodowiskowym, ilustruje to tabela 1.

Tabela 1. Konteksty prośrodowiskowe obszarów badawczych pedagogiki pracy

\begin{tabular}{|l|l|l|}
\hline Lp. & $\begin{array}{l}\text { Nazwa obszaru ba- } \\
\text { dawczego pedagogiki } \\
\text { pracy }\end{array}$ & Nurt prośrodowiskowy \\
\hline 1. & $\begin{array}{l}\text { Cele kształcenia i ich } \\
\text { analiza w powiąza- } \\
\text { niu z przemianami } \\
\text { kultury, gospodarki } \\
\text { i rynku pracy }\end{array}$ & $\begin{array}{l}\text { - rozwój świadomości prośrodowiskowej poprzez } \\
\text { edukację środowiskową }\end{array}$ \\
\hline 2. & $\begin{array}{l}\text { Podział pracy i wyod- } \\
\text { rębnianie zawodów } \\
\text { oraz opracowywa- } \\
\text { nie charakterystyk } \\
\text { zawodowych }\end{array}$ & $\begin{array}{l}\text { - ukazywanie prośrodowiskowych treści i charak- } \\
\text { teru pracy, } \\
\text { - promowanie nowych zawodów, przyjaznych śro- } \\
\text { dowisku przyrodniczemu, } \\
\text { - wzbogacenie treści charakterystyk zawodowych } \\
\text { o aspekty prośrodowiskowe }\end{array}$ \\
\hline 3. & $\begin{array}{l}\text { Kryteria doboru treści } \\
\text { kształcenia, dostoso- } \\
\text { wanych do kierunków } \\
\text { i poziomów kształce- } \\
\text { nia zawodowego }\end{array}$ & $\begin{array}{l}\text { - upowszechnianie edukacji środowiskowej na każ- } \\
\text { - wzbogacanie treści kształcenia zawodowego o za- } \\
\text { gadnienia edukacji środowiskowej }\end{array}$ \\
\hline
\end{tabular}




\begin{tabular}{|c|c|c|}
\hline Lp. & $\begin{array}{l}\text { Nazwa obszaru ba- } \\
\text { dawczego pedagogiki } \\
\text { pracy }\end{array}$ & Nurt prośrodowiskowy \\
\hline 4. & $\begin{array}{l}\text { Podstawowe zagad- } \\
\text { nienia wychowawcze } \\
\text { związane z kształto- } \\
\text { waniem osobowości } \\
\text { zawodowej i etyki } \\
\text { zawodowej }\end{array}$ & $\begin{array}{l}\text { - udział wielu podmiotów w kształtowaniu świa- } \\
\text { domości ekologicznej człowieka: od domu rodzin- } \\
\text { nego po edukację formalną, a także nieformalną } \\
\text { i incydentalną, } \\
\text { - dostrzeganie w treściach edukacji środowiskowej } \\
\text { ich wychowawczych aspektów, } \\
\text { - kształtowanie postaw i zachowań prośrodowisko- } \\
\text { wych jako świadomości ekologicznej, } \\
\text { - ukazywanie pożądanych dla procesów pracy } \\
\text { zachowań, wyrażonych należytym stosunkiem } \\
\text { do zagospodarowywania odpadów surowcowych } \\
\text { i poprodukcyjnych, stosownie do ich właściwości } \\
\text { i procedur ich dalszego zagospodarowywania, } \\
\text { - oszczędne gospodarowanie surowcami i materia- } \\
\text { łami pomocniczymi oraz mediami jako wyraz nie } \\
\text { tylko oszczędności i gospodarności, ale też stosunku } \\
\text { do przyrody i potrzeby jej ochrony }\end{array}$ \\
\hline 5. & $\begin{array}{l}\text { Metodyka kształcenia } \\
\text { i doskonalenia zawo- } \\
\text { dowego oraz podstawy } \\
\text { dydaktyki zawodowej }\end{array}$ & $\begin{array}{l}\text { - objęcie edukacji środowiskowej metodyką kształ- } \\
\text { cenia zawodowego, } \\
\text { - objęcie edukacji środowiskowej procesami szkole- } \\
\text { nia, dokształcania i doskonalenia zawodowego }\end{array}$ \\
\hline 6. & $\begin{array}{l}\text { Badania i materiały } \\
\text { zawodoznawcze dla } \\
\text { orientacji i poradni- } \\
\text { ctwa zawodowego }\end{array}$ & $\begin{array}{l}\text { - analizowanie treści zawodów, w tym specyficznych } \\
\text { dla pracy w nich środków i przedmiotów pracy, } \\
\text { technologii, oraz łączenia tej wiedzy z warunkami } \\
\text { pracy (właściwościami, które sprawiają, że jest } \\
\text { zdrowa i bezpieczna oraz wiąże się ze zdrowymi } \\
\text { i przyjaznymi dla człowieka wytworami pracy), } \\
\text { - analizowanie właściwości odpadów poproduk- } \\
\text { cyjnych i sposobów ich zagospodarowania, aby nie } \\
\text { dopuścić do degradacji środowiska przyrodniczego } \\
\text { i pozostawić je w jak najmniej zmienionej postaci } \\
\text { dla kolejnych pokoleń, chcácych żyć, pracować i od- } \\
\text { poczywać w otoczeniu, które jest w miarę przyjazne, } \\
\text { - upowszechnianie nowego stylu porady zawodowej, } \\
\text { ukierunkowanej prozawodowo i prośrodowiskowo, } \\
\text { - popularyzowanie zawodów prośrodowiskowych } \\
\text { i rynkowych szans na podjęcie w nich pracy }\end{array}$ \\
\hline
\end{tabular}




\begin{tabular}{|l|l|l|}
\hline Lp. & $\begin{array}{l}\text { Nazwa obszaru ba- } \\
\text { dawczego pedagogiki } \\
\text { pracy }\end{array}$ & Nurt prośrodowiskowy \\
\hline 7. & $\begin{array}{l}\text { Dokształcanie i do- } \\
\text { skonalenie zawodowe } \\
\text { w ścisłym powiązaniu } \\
\text { z zakładem pracy }\end{array}$ & $\begin{array}{l}\text { - uczynienie treści prośrodowiskowych najważniej- } \\
\text { szymi w procesach dokształcania i doskonalenia } \\
\text { zawodowego, zwłaszcza na stanowiskach pracy } \\
\text { ściśle połączonych z produkcją i jej oddziaływaniem } \\
\text { na środowisko przyrodnicze, } \\
\text { - kształtowanie postaw prośrodowiskowych w pro- } \\
\text { cesach dokształcania i doskonalenia zawodowego } \\
\text { człowieka, w tym pracownika i obywatela }\end{array}$ \\
\hline 8. & $\begin{array}{l}\text { Warunki materialne } \\
\text { realizacji kształce- } \\
\text { nia i doskonalenia } \\
\text { zawodowego }\end{array}$ & $\begin{array}{l}\text { - nawiązywanie współpracy z zakładami utylizacji } \\
\text { odpadów, oczyszczalniami ścieków oraz poznawa- } \\
\text { nie zakładowych rozwiązań w rozwoju i upowszech- } \\
\text { nianiu postaw prośrodowiskowych, ich wyrabianie } \\
\text { w procesach edukacyjnych: od kształcenia po } \\
\text { dokształcanie i doskonalenie zawodowe, } \\
\text { - wdrażanie sposobów zagospodarowywania odpa- } \\
\text { dów i ścieków w przedsiębiorstwach }\end{array}$ \\
\hline 9. & $\begin{array}{l}\text { Problemy kierowania } \\
\text { versus kontrola i ocena } \\
\text { wyników kształcenia } \\
\text { zawodowego oraz } \\
\text { badanie przydatności } \\
\text { zawodowej }\end{array}$ & $\begin{array}{l}\text { - wpisanie w problematykę kierowania i zarządzanie } \\
\text { zagadnień ekologicznych, a także upowszechnianie } \\
\text { koncepcji zarządzania przez ekologię (Pocztowski } \\
\text { 2o13, s. 46), } \\
\text { - wpisanie zagadnień prośrodowiskowych w proble- } \\
\text { matykę przydatności zawodowej pracownika, } \\
\text { - ocenianie postaw prośrodowiskowych nie tylko } \\
\text { jako elementu dużej wrażliwości środowiskowej } \\
\text { pracownika, ale i jego wysokiej moralności zawodo- } \\
\text { wej i obywatelskiej, wyrażonej wzięciem odpowie- } \\
\text { dzialności człowieka, czyli pracownika i obywatela, } \\
\text { za stan środowiska przyrodniczego }\end{array}$ \\
\hline $\begin{array}{l}\text { Zagadnienia } \\
\text { pedeutologiczne }\end{array}$ & $\begin{array}{l}\text { - objęcie zagadnień dotyczących środowiska na- } \\
\text { turalnego kształceniem pedeutologicznym bez } \\
\text { względu na specjalistyczny nurt przygotowywania } \\
\text { nauczycieli, w tym kształcenia zawodowego, } \\
\text { - uczynienie nauczyciela jednym z głównych am- } \\
\text { basadorów ochrony środowiska przyrodniczego, } \\
\text { promujących i propagujących prośrodowiskowe } \\
\text { postawy }\end{array}$ \\
\hline
\end{tabular}

Źródło: opracowanie własne. 
Treść tabeli 1. ukazuje, jak nadanie prośrodowiskowego wymiaru pedagogice pracy prowadzi do kształtowania świadomości ekologicznej obejmującej całe życie, jako zadania edukacyjnego wpisanego w działania wszystkich podmiotów odpowiedzialnych za życie i rozwój człowieka, począwszy od jego narodzin, następnie jego rozwój dokonujący się w rodzinie, przygotowanie do edukacji, uczestnictwo w niej, a następnie pracę i wypoczynek. Żaden z tych etapów nie powinien marginalizować przyrody, ale musi ją eksponować jako niezwykle ważną i cenną dla życia i wypoczynku człowieka. Środowisko przyrodnicze jest bowiem miejscem, gdzie krzyżują się treści środowiskowe z problemami wychowawczymi, istotnymi dla życia człowieka. Podtrzymanie tej integracji w różnych okresach i miejscach wymaga nieustannego i mającego różne cele obcowania człowieka ze środowiskiem przyrodniczym, a w ślad za tym - istnienia działań, które powinny ponad wszystko cenić trwałość oraz uniwersalność przyrody, pozwalając jej przetrwać dla kolejnych pokoleń. Świadomi tego zadania powinni być szczególnie pedagodzy pracy, którzy dotychczas nie dostrzegali dewastacji środowiska poprzez pracę zawodową człowieka i towarzyszące jej procesy oraz nie odczuwali potrzeby prośrodowiskowych oddziaływań wychowawczych, ani podczas edukacji, ani w czasie samej pracy zawodowej. Najważniejszy zawsze był zysk, przez co niekontrolowana działalność człowieka doprowadzała do „niezrównoważonego wykorzystania przyrody, powodując niebezpieczeństwo jej zniszczenia” (Okoń 1992, s. 152). Człowiek, dalej postępując w nieprzyjazny dla otoczenia sposób, w konsekwencji doprowadzić może do sytuacji, że kiedyś „on sam padnie ofiarą tej degradacji” (Paweł IV, za: Franciszek 2015, s. 4), wpisanej w „katastrofę ekologiczną pod wpływem eksplozji cywilizacji przemysłowej" (tamże, s. 4). Człowiek jako twórca wszystkiego powinien być świadomy, że nawet „najbardziej niezwykłe postępy naukowe, najbardziej niesamowite osiągnięcia techniczne, najcudowniejszy rozwój gospodarczy nie łączy się z automatycznym postępem społecznym i moralnym, w ostatecznym rachunku zwracają się one przeciw człowiekowi” (tamże; por. Nowacki 1964, s. 84).

Prośrodowiskowy wymiar pedagogiki pracy postulowany był przez jej twórcę Tadeusza W. Nowackiego już w jednym z jego pierwszych ważnych dzieł Wychowanie a cywilizacja techniczna (1964), czyli kilka lat przed pojawieniem się pedagogiki pracy, co stało się dopiero w 1972 roku na mocy Uchwały nr 162 Rady Ministrów $z$ dnia 15 czerwca 1972 r. w sprawie utworzenia Instytutu Kształcenia Zawodowego. Do problematyki prośrodowiskowej Tadeusz W. Nowacki powrócił po ponad 30 latach, kiedy to w sposób bardzo dobitny odniósł się do potrzeby należytego zagospodarowania odpadów towarzyszących pracy człowieka, eksponując te kwestie m.in. w słynnym schemacie ilustrującym rodzaje tworzyw pracy i czynności z nimi związanych w procesie pracy, co prezentuje rysunek 1. 


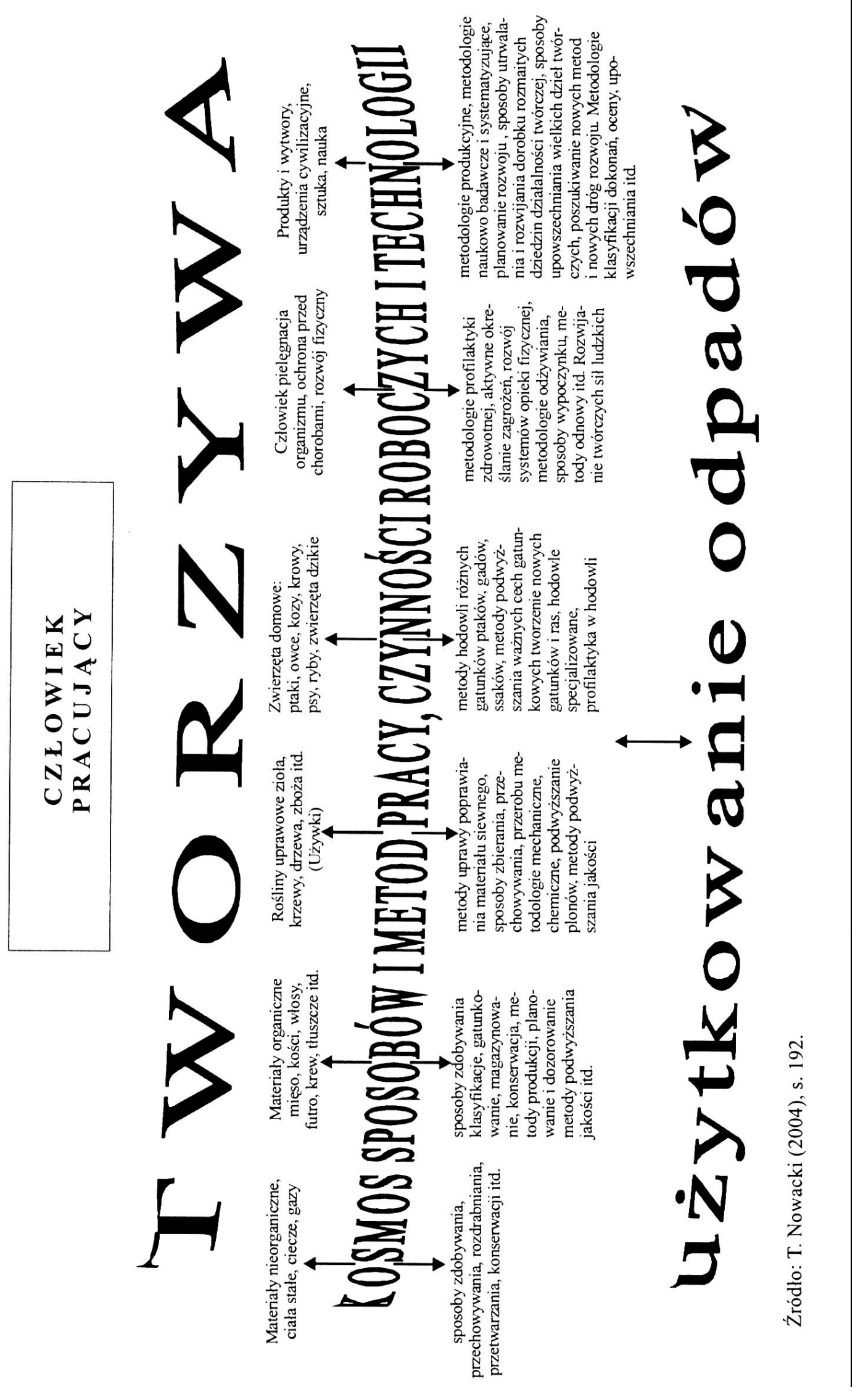


Wyeksponowane na powyższym rysunku elementy procesu pracy powinny pomóc promować i rozwijać pracę $\mathrm{w}$ środowiskowo przyjaznych człowiekowi warunkach i dążyć - jak napisał Tadeusz W. Nowacki - do poprawy warunków pracy, zwłaszcza w zakresie jej uciążliwości za sprawą zanieczyszczonej atmosfery w kopalniach, hutach, fabrykach chemicznych (Nowacki 2008, s. 35). Jest to również reakcja na rozwój ruchów w obronie środowiska przyrodniczego (tamże, s. 35; zob. także Gromkowska-Melosik 2006, s. 426-428), o czym powinni pamiętać konstruktorzy procesów pracy i nowych technologii. Celem przywołanych postaw prośrodowiskowych jest nie tylko pełniejsze wykorzystanie wszelkiego rodzaju potencjału i maksymalizacja zysku producentów, ale również rozwój działań proekologicznych, ukierunkowujących gospodarkę na potrzeby człowieka i czystość otoczenia. W tym humanizacyjnym podejściu upatrywać należy uzdrowienia gospodarki (Nowacki 2008, s. 35) i promowania innego jej modelu, w którym dominują zawody usługowe, wydające się bardziej przyjaznymi dla człowieka, a także zawody prośrodowiskowe, które wręcz eksponują podejście proekologiczne w pracy (Baraniak 2015, s. 82-82; Baraniak 2016, s. 36). Przykłady takich zawodów ilustruje tabela 2.

Tabela 2. Wybrane prośrodowiskowe zawody objęte Klasyfikacją Zawodów i Specjalizacji (Dz.U. z dn. 28 kwietnia 2014 r.)

\begin{tabular}{|l|l|l|}
\hline Lp. & Nazwa zawodu & Kod zawodu \\
\hline 1. & Operator spalarni odpadów komunalnych & 313206 \\
\hline 2. & Operator urządzeń oczyszczania ścieków & 313208 \\
\hline 3. & Edukator ekologiczny & 325501 \\
\hline 4. & Technik analizy i monitoringu środowiska & 325508 \\
\hline 5. & Technik bezpieczeństwa pracy & 325509 \\
\hline 6. & Inspektor ochrony środowiska & 325504 \\
\hline 7. & Strażnik ochrony przyrody/środowiska & 325507 \\
\hline 8. & Ładowacz nieczystości stałych & 961102 \\
\hline 9. & Sortowacz surowców wtórnych & 961201 \\
\hline 10. & Robotnik oczyszczalni miasta & 961301 \\
\hline 11. & Ładowacz nieczystości płynnych & 961101 \\
\hline 12. & Operator urządzeń utylizacji surowców zwierzęcych & 818902 \\
\hline 13. & Aparatowy urządzeń utylizacji odpadów toksycznych & 313201 \\
\hline 14. & Technik ochrony środowiska & 325511 \\
\hline 15. & Technik inżynierii środowiska i melioracji & 311208 \\
\hline 16. & Operator urządzeń oczyszczania ścieków & 313208 \\
\hline
\end{tabular}

Źródło: opracowanie własne na podstawie KZiS z 2014 r., wprowadzanej na rynek pracy od $2015 \mathrm{r}$. 
Treść tabeli 2. unaocznia rynkowe zainteresowanie zawodoznawstwa problematyką ochrony środowiska, czego wyrazem są nowe zawody o tym profilu. Fakt zamieszczenia ich w oficjalnej klasyfikacji świadczy o ich oczywistej przydatności rynkowej, a nazewnictwo wskazuje na coraz intensywniejsze zainteresowanie decydentów sprawujących władzę na różnym poziomie problemami ochrony środowiska. Kolejne propozycje tego typu zawodów czekają też na ustawodawcze decyzje. Interesującymi przyszłościowymi zawodami wydają się być np.: doradca gospodarowania odpadami, technik gospodarki odpadami, specjalista odpadów komunalnych itp. (Sławińska, Symela 2014, s. 99) czy też promotor ochrony środowiska w przedsiębiorstwie (Kacak, Skoczylas 2013, s. 139). Tak sprofilowane zawody należy traktować jako przydatne w holistycznym modelu zarządzania organizacją i jej zasobami (Pocztowski 2013, s. 46), który nie powinien obecnie pomijać problemów ekologii, wpisanych w model teorii zarządzania (zob. rysunek 4.).

Przykładem poważnego liczenia się z kwestiami natury ekologicznej w procesie przygotowania zawodowego jest projekt Leonardo de Vinci „Rozwój Standardu Kwalifikacji GreenPoint i jego wdrażanie w małych przedsiębiorstwach branży metalowej" (Sławińska, Symela 2014, s. 91). Uwzględniono w nim takie kluczowe problemy jak np.:

1. przestrzeganie ustawodawstwa z zakresu ochrony środowiska;

2. identyfikacja i zapewnienie zgodności wymogów środowiskowych występujących w przedsiębiorstwie;

3. identyfikacja potencjalnych źródeł zanieczyszczeń środowiska, pochodzących $\mathrm{z}$ procesów produkcyjnych przedsiębiorstwa;

4. ocenianie rozwiązań ograniczających lub eliminujących emisję zanieczyszczeń środowiska itp.

Są to przykładowe zadania, wybrane z listy aż 25 (tamże) o takim charakterze. Ukazują one nie tylko współczesną tendencję, ale też potrzebę upowszechniania problemów ekologicznych tak, aby nie były obce ani środowisku wewnętrznemu pracy, ani zewnętrznemu (Borkowska 2006, s. 331; Pocztowski 2013, s. 46). Kwestia ich wpływu na samą pracę wpisuje się w sferę kształtowania osobowości człowieka, dzięki której ludzie ze swoimi cechami osobowościowymi, usposobieniem i dążeniem do życia w ładzie i porządku będą taki proekologiczny model pracy preferowali. Pozwoli to kształtować czystsze i przyjaźniejsze dla nich i ich otoczenia stanowiska pracy, wolne od niepotrzebnych materiałów i odpadów, które bardzo często niekorzystnie wpływają na stan środowiska przyrodniczego. Z kolei aspekt wpływu na otoczenie zewnętrzne pracy, będący przeciwieństwem poprzedniego modelu gospodarowania, skoncentrowanego głównie na zysku oraz dostosowaniu się do aktualnego ustawodawstwa prawnego (Ustawa o odpadach 20o1), wyraża się w potrzebie rezygnacji z niego na rzecz przyjaznego środowisku naturalnemu dzięki takich działaniom, jak np. sortowanie odpadów, promocja technologii przyjaznych środowisku, zakładowe oczyszczalnie ścieków itp. Ten nowy organizacyjny i zawodoznawczy trend to wynik przejścia na organizację pracy przyjazną środowisku 
przyrodniczemu, wyrażający się nie tylko sortowaniem, usuwaniem i zagospodarowywaniem odpadów poprodukcyjnych, ale i dążeniem do ich minimalizacji oraz zastępowaniem tradycyjnych źródeł zasilania i wytwarzania energii nowszymi, mniej uciążliwymi dla przyrody, jak naturalne źródła energii, np. poprzez instalację paneli słonecznych, budowę z nich tzw. poletek ekologicznych czy szersze wykorzystanie energii wiatrowej. W ten ekologiczny kontekst wpisują się również tradycyjne treści pracy w zawodach, które są tworzywami procesu pracy (Nowacki 2004, S. 192), a wśród nich cała gama: 1. środków pracy i materiałów pomocniczych, niezbędnych w procesach technologicznych (Baraniak 2001), oraz 2. przedmiotów pracy: urządzeń, maszyn o różnym poziomie techniki czy całych zespołów produkcyjnych, tj. tzw. ciągów technologicznych. Ich obecność w procesach pracy Tadeusz W. Nowacki (2004) nazwał kosmosem metod i technik procesów pracy, a dopełnił je 3. czynnościami i technologiami, obejmującymi również gospodarkę odpadami (Nowacki, Jeruszka 2004, s. 31) (zob. rysunek 1.). Ich liczba jest pochodną złożoności procesu pracy, jej organizacyjnej kultury, wpisującej się we właściwą cywilizację, a stanowiącej przedmiot rozlicznych raportów, w tym m.in. Alvina Tofflera $(1995,1986,1974)$. Autor ten wyodrębnił i określił historyczne przemiany społeczne, które nazwał trzema falami - agrarną, industrialną i postindustrialną. Każda z nich ma inne środowiskowe, czyli ekologiczne, oblicze, a ich charakter dobrze oddaje opis cech podstawowych modeli cywilizacyjnych, co ujmuje treść tabeli 3 .

Tabela 3. Cechy podstawowych modeli cywilizacji

\begin{tabular}{|l|l|l|l|l|}
\hline Lp. & Kategoria opisu & $\begin{array}{l}\text { Cywilizacja } \\
\text { agrarna - przed- } \\
\text { industrialna }\end{array}$ & $\begin{array}{l}\text { Cywilizacja } \\
\text { przemysłowa - } \\
\text { industrialna }\end{array}$ & $\begin{array}{l}\text { Cywilizacja } \\
\text { informacyjna - } \\
\text { postindustrialna }\end{array}$ \\
\hline 1. & Wartości & Ziemia & $\begin{array}{l}\text { Kapitał, siła } \\
\text { robocza, środki } \\
\text { produkcji }\end{array}$ & $\begin{array}{l}\text { Informacja, } \\
\text { wiedza, } \\
\text { kompetencje }\end{array}$ \\
\hline 2. & Zasoby & Surowce & Energia & Informacje \\
\hline 3. & Sposób działania & $\begin{array}{l}\text { Uprawianie } \\
\text { (dod. } \\
\text { B. Baraniak) }\end{array}$ & $\begin{array}{l}\text { Wydobywanie } \\
\text { (zmiana } \\
\text { B. Baraniak) } \\
\text { i wytwarzanie }\end{array}$ & Przetwarzanie \\
\hline 4. & $\begin{array}{l}\text { Technologie } \\
\text { definicyjne/ } \\
\text { kluczowe }\end{array}$ & $\begin{array}{l}\text { Technologie } \\
\text { upraw, } \\
\text { chowu (dod. } \\
\text { B. Baraniak) } \\
\text { i hodowli }\end{array}$ & $\begin{array}{l}\text { Technologie } \\
\text { energetyczne } \\
\text { i maszynowe }\end{array}$ & $\begin{array}{l}\text { Technologie } \\
\text { informacyjne }\end{array}$ \\
\hline
\end{tabular}




\begin{tabular}{|l|l|l|l|l|}
\hline Lp. & Kategoria opisu & $\begin{array}{l}\text { Cywilizacja } \\
\text { agrarna - przed- } \\
\text { industrialna }\end{array}$ & $\begin{array}{l}\text { Cywilizacja } \\
\text { przemysłowa - } \\
\text { industrialna }\end{array}$ & $\begin{array}{l}\text { Cywilizacja } \\
\text { informacyjna - } \\
\text { postindustrialna }\end{array}$ \\
\hline 5. & Wyniki & $\begin{array}{l}\text { Produkty } \\
\text { żywnościowe }\end{array}$ & $\begin{array}{l}\text { Wytwory } \\
\text { przemysłowe }\end{array}$ & $\begin{array}{l}\text { Utwory i usługi } \\
\text { cyfrowe }\end{array}$ \\
\hline 6. & Oddziaływanie & Na naturę & Na tworzywo & Na osoby \\
\hline 7. & Charakter pracy & Pracochłonna & Kapitałochłonna & Wiedzochłonna \\
\hline 8. & Ikony & $\begin{array}{l}\text { Pług, chomąto, } \\
\text { kierat }\end{array}$ & $\begin{array}{l}\text { Maszyna, } \\
\text { fabryka }\end{array}$ & $\begin{array}{l}\text { Mikroprocesor, } \\
\text { parakomputer, } \\
\text { komputer }\end{array}$ \\
\hline
\end{tabular}

Źródło: Furmanek 2015, s. 18.

W modele te doskonale wpisują się nowe zawody, adekwatne do przemian społecznych ewoluujących od ery agrarnej poprzez przemysłową do postprzemysłowej. Pomimo innych wartości każdej z tych er, to ostania nie pozostaje obojętna dla środowiska przyrodniczego, w pełni korzysta bowiem z osiągnięć dorobku cywilizacyjnego, proponującego indywidualne opakowania, głównie plastikowe, lekkie, ale za to niebiodegradowalne, czyli nieprzyjazne dla środowiska. Podobnie jest z modą na osobiste komputery, a także mnogością sprzętu RTV w domostwach, $\mathrm{w}$ tym $\mathrm{z}$ ich instalowaniem $\mathrm{w}$ gabinetach, łazienkach. Jeśli dopełnimy to światem pracy, preferującym zatrudnienie głównie w sektorze usług, w którym tylko rzekomo dominują mniej agresywne technologie i zawody oddziałujące na środowisko przyrodnicze, to stan środowiska przyrodniczego nie może ulegać poprawie. Ta nowa moda generuje nadmierne zużywanie energii, tym samym powodując zwiększoną emisję spalin do atmosfery, jak również procesy mało korzystne dla przyrody i żyjącego w niej człowieka oraz jego zdrowia. W tabeli 3. podano przykłady kontekstów proekologicznych i zestawiono ze sobą cechy poszczególnych er. Pozwalają one porównać ich różne środowiskowe oblicza, nie tylko zawodoznawcze. Najbardziej niekorzystnie w tym względzie przedstawia się wciąż era przemysłowa z wielkim przemysłem wydobywczym i ciężkim, nastawionym na wydobycie i przetwórstwo złóż naturalnych, często w niekontrolowanym wymiarze. Jeśli doda się do tego wciąż niską wrażliwość człowieka na czystość środowiska, czego efektem są zdewastowana roślinność skwerów, lasów, nienadający się do kąpieli oraz uprawiania sportów wodnych czy zespołowej i indywidualnej rekreacji stan wód rzek, zalewów i jezior, to kształtowanie postaw prośrodowiskowych wydaje się zasadnym działaniem, aby przywrócić chociażby należną rolę przyrody w życiu człowieka. One jednak nie pozostają obojętne dla środowiska, głównie z powodu nadmiernej liczby nowoczesnych narzędzi pracy, takich jak komputery osobiste czy skomplikowane infosfery, sieci kanałów komunikacji itp. (Denek 2008). Może się wydawać, że w wyniku ich pracy powstaje mniej odpadów, ale jednak zwiększone zatrudnienie w tych obszarach oraz wyższe potrzeby ludzkości sprawiają, 
że środowisko naturalne wciąż jest zagrożone. Dzieje się tak za sprawą niekontrolowanego sposobu korzystania $z$ osobistych sprzętów i wyposażenia domowego, zużywającego ogromne ilości energii wytwarzanej wciąż konwencjonalnymi sposobami, czyli poprzez spalanie głównego nośnika energetycznego - węgla, którego spaliny wpisują się w emisję dwutlenku węgla (Komunikat Komisji Europejskiej „Europa 2020...” 2010), czynnika niekorzystnego dla środowiska przyrodniczego. Dlatego gospodarowanie odpadami to jeden $\mathrm{z}$ największych i najbardziej złożonych problemów współczesnego świata (Sławińska, Symela 2014, s. 91). Kolejny to wielozadaniowe urządzenia typu automatycznego, napędzane klasycznymi źródłami energetycznymi, zużywające ogromne ilości energii i powodujące tzw. efekt cieplarniany, odczuwany i dostrzegany przez każdego obywatela ziemi (Komunikat Komisji Europejskiej „Europa 2020...”, 2010). Jeśli dodamy do tego ogromne ilości jednorazowych opakowań, wykonanych z materiałów niebiodegradowalnych, to przyszłość środowiska przyrodniczego nie jawi się w jasnym świetle. Dlatego trzeba postrzegać je holistycznie, czyli nie tylko w kontekście człowieka, ale również roślinności, zwierząt itp. - w celu umożliwienia im życia w czystym i przyjaznym otoczeniu. Zadanie to należy uznać za priorytet współczesnego społeczeństwa. Wyraża się ono w dążeniu do poprawy ich warunków życia, w który wpisuje się kolejny - kierowany do pracodawcy poszukującego bardziej mobilnego i elastycznego pracownika, posiadającego tzw. miękkie kompetencje. Do tych ostatnich zaliczyć można - poza dobrą, solidną i rzetelną pracą - również dużą wrażliwością ekologiczną (Pocztowski 2013, s. 46-50). Ta z kolei wymaga dalszej edukacji, a także umiejętności, do których zalicza się przede wszystkim dobrą organizację pracy i zarządzania nią, a przede wszystkim personelem, w kontekście problemów prośrodowiskowych ujętych w raporcie Skills for GreenJob (2010). Konsekwencją tych umiejętności powinna być praca oparta na świadomym zużywaniu surowców i materiałów pomocniczych, wynikającym z rygorów technologicznych. Tylko taka organizacja pracy może przyczynić się do zminimalizowania odpadów zagrażających nie tylko środowisku naturalnemu, ale i zdrowiu pracowników, a więc do tego, by praca odbywała się w bezpiecznych i higienicznych warunkach, czyli była przyjazna człowiekowi, a tym samym środowisku przyrodniczemu. Są to wybrane przykłady współczesnych wymagań ekologicznych, do których zarówno pracownicy, jak i pracodawcy powinni być przygotowani, a ich wiedza na ten temat w czasie zatrudnienia powinna podlegać aktualizacji. Zadanie edukacji postzawodowej wiąże się z całożyciowym wymiarem edukacji prośrodowiskowej. Tylko wówczas można liczyć na świadome proekologiczne postawy, minimalizujące potencjalne zagrożenia ze strony pracy dla środowiska oraz zdrowia pracownika, i promowanie bezpiecznych warunków do jej wykonywania. W wypełnieniu tejże idei niezbędne powinny stać się plany i programy oraz strategie dotyczące odpowiedniego, czyli bezpiecznego i ekonomicznego, usuwania odpadów gospodarczych, przemysłowych, medycznych itp. czy wreszcie promocji i upowszechniania systemów oczyszczania ścieków, usuwania odpadów, ograniczania emisji spalin do otoczenia, dbania 
o jakość wody wykorzystywanej w przemyśle i działalności gospodarczej oraz gospodarstwach domowych, a także wód przeznaczonych do celów rekreacyjnych itp. W realizacji tak złożonych zadań pomocne są zachowania proekologiczne człowieka w miejscach pracy, ale także podczas wypoczynku, prowadzenia domu itp. Są to nowe społecznie oczekiwane zadania, stawiane współcześnie pedagogice pracy, starającej się realizować program całożyciowego wychowania, np. do pracy, w pracy oraz przez pracę. Analogiczne mogłyby dotyczyć problematyki ekologicznej. Istnieją już pakiety niezbędnych w tym zakresie dokumentów: polskie (Ustawa o odpadach 2001), światowe (Franciszek 2015) oraz europejskie (Komunikat Komisji Europejskiej „Europa 2020...” 2010), uznające środowisko przyrodnicze za wartość oraz zwracające uwagę na żyjącego w nim człowieka, który chce pracować, żyć i wypoczywać w czystym i zdrowym środowisku. Dlatego przed pedagogiką pracy stają wyzwania związane z promocją pracy i jej organizacji, skoncentrowanych na minimalizacji potencjalnych zagrożeń dla człowieka, jego życia i zdrowia. Sprostać temu mogą tylko programy upowszechniające czyste środowiska, najpierw pracy, a potem przyrodnicze, i coraz intensywniejsze zainteresowanie decydentów - na różnym poziomie - priorytetowymi problemami ochrony środowiska. Jednym $\mathrm{z}$ ważnych działań na ich rzecz wydaje się zgłaszanie nowych zawodów do KZiS, tzw. nowych zielonych zawodów (Sławińska, Symela 2014, s. 91). Nie tylko one, ale również nowe organizacyjne rozwiązania przyjazne dla człowieka i jego otoczenia, preferujące czystsze i lepiej zorganizowane stanowiska pracy, czyli wolne od niepotrzebnych materiałów i odpadów, wpiszą się w działania prośrodowiskowe, takie jak m.in. sortowanie odpadów, promocja technologii przyjaznych środowisku, zakładowe oczyszczalnie ścieków itp.

\section{Prośrodowiskowy wymiar przedmiotu badań pedagogiki pracy}

Wzrastające z roku na rok zagrożenie dla środowiska naturalnego nie może pozostać obce pedagogice pracy, która powinna nareszcie zacząć korzystać z myśli jej twórcy Tadeusza W. Nowackiego i nauki społecznej Kościoła, upowszechnianej przez ostatnich papieży: Pawła VI, Jana XXIII, Jana Pawła II i Franciszka. Tylko wspólne, zintegrowane działania mogą poprawić wciąż niską świadomość ekologiczną społeczeństwa, prowadząc do całożyciowej edukacji prośrodowiskowej (zob. tabela 4.). Jest to jedno z działań, które może pozwolić na bezpieczniejszy byt oraz pracę człowieka na ziemi. Zatem edukacja pozostaje nie tylko istotną kwestią w rozwoju człowieka i jego pracy, ale i w kształtowaniu odpowiednich postaw, $\mathrm{w}$ tym m.in. zawodowych oraz tak współcześnie pożądanych prośrodowiskowych. Te ostanie pozostają wciąż ważne dla życia człowieka, jego nieustanych kontaktów z przyrodą, korzystania z jej uroków, co będzie możliwe wraz z upowszechnianiem postaw prośrodowiskowych również w pracy zawodowej. $\mathrm{W}$ związku z tym przedmiot badań pedagogiki pracy, opisany triadą człowiek - wychowanie - praca (Nowacki 1978; Wiatrowski 2005), nie powinien dłużej pozostawać obojętny na 
oddziaływanie procesów pracy, a pracujący człowiek musi przejąć odpowiedzialność za stan środowiska przyrodniczego, powinno to zostać włączone w teorie pedagogiki pracy wraz z edukacją środowiskową i jej całożyciowym wymiarem, analogicznym do poradnictwa zawodowego czy problemów wychowania i pracy skorelowanych $\mathrm{z}$ procesami edukacji. Tylko ujęta w ten sposób edukacja środowiskowa, z jednym $\mathrm{z}$ jej ważnych celów wychowawczych, czyli dążeniem do kształtowania postaw prośrodowiskowych człowieka na różnych etapach jego życia i przygotowania do wielu ról zawodowych, powinna wpisać się w zadania aktualnej reformy systemu edukacji. Propozycję zadań edukacyjnych ważnych dla kształtowania świadomości ekologicznej grup społecznych w nurcie struktur pedagogiki pracy (Nowacki 1982, s. 118-120) oraz modelu edukacji permanentnej (Wiatrowski 2005, s. 357) ilustruje tabela 4.

Tabela 4. Edukacja środowiskowa w całożyciowej idei kształtowania świadomości ekologicznej człowieka

\begin{tabular}{|c|c|c|c|c|}
\hline Lp. & $\begin{array}{l}\text { Okres rozwo- } \\
\text { jowy podmiotu } \\
\text { uczącego }\end{array}$ & $\begin{array}{l}\text { Lata } \\
\text { życia }\end{array}$ & $\begin{array}{l}\text { Właściwości działań } \\
\text { pedagogicznych }\end{array}$ & $\begin{array}{l}\text { Wyniki w powią- } \\
\text { zaniu z pracą }\end{array}$ \\
\hline 1. & $\begin{array}{l}\text { Wychowanie } \\
\text { naturalne }\end{array}$ & $0-4$ & $\begin{array}{l}\text { Edukacja środowiskowa } \\
\text { w rodzinie, polegająca na } \\
\text { kontakcie z otoczeniem przy- } \\
\text { rodniczym, potrzebie tego } \\
\text { kontaktu, poprzez wdrażanie } \\
\text { dzieci od najmłodszych lat } \\
\text { do kształtowania postaw } \\
\text { prośrodowiskowych, na } \\
\text { które składa się: ochrona } \\
\text { przyrody, pozytywny stosu- } \\
\text { nek do niej, oszczędne użyt- } \\
\text { kowanie nośników i takich } \\
\text { jak prąd woda, segregacja } \\
\text { odpadów itp. }\end{array}$ & \multirow{2}{*}{$\begin{array}{l}\text { Poznawanie } \\
\text { środowiska } \\
\text { przyrodniczego } \\
\text { i dostrzeganie } \\
\text { skutków jego de- } \\
\text { gradacji poprzez } \\
\text { różne czynniki. } \\
\text { Kształtowanie } \\
\text { postaw prośrodo- } \\
\text { wiskowych po- } \\
\text { przez wdrażanie } \\
\text { do segregowania } \\
\text { odpadów. } \\
\text { Kształtowanie } \\
\text { postaw prośrodo- } \\
\text { wiskowych po- } \\
\text { przez wdrażanie } \\
\text { do oszczędności } \\
\text { w zużyciu energii } \\
\text { i wody }\end{array}$} \\
\hline 2. & $\begin{array}{l}\text { Okres } \\
\text { przedszkolny }\end{array}$ & $4-7$ & $\begin{array}{l}\text { Edukacja środowiskowa } \\
\text { w przedszkolu, kontynu- } \\
\text { ująca tę zapoczątkowaną } \\
\text { w domu rodzinnym, roz- } \\
\text { wój postaw i zachowań } \\
\text { prośrodowiskowych }\end{array}$ & \\
\hline
\end{tabular}




\begin{tabular}{|c|c|c|c|c|}
\hline Lp. & $\begin{array}{l}\text { Okres rozwo- } \\
\text { jowy podmiotu } \\
\text { uczącego }\end{array}$ & \begin{tabular}{|l} 
Lata \\
życia
\end{tabular} & $\begin{array}{l}\text { Właściwości działań } \\
\text { pedagogicznych }\end{array}$ & $\begin{array}{l}\text { Wyniki w powią- } \\
\text { zaniu z pracą }\end{array}$ \\
\hline 3. & $\begin{array}{l}\text { Okres wczes- } \\
\text { noszkolny - } \\
\text { nauczanie } \\
\text { zintegrowane }\end{array}$ & $7-10$ & $\begin{array}{l}\text { Edukacja środowiskowa } \\
\text { kontynuująca tę zapo- } \\
\text { czątkowaną w domu ro- } \\
\text { dzinnym, a następnie } \\
\text { w przedszkolu, w kierunku } \\
\text { rozwoju postaw i zachowań } \\
\text { prośrodowiskowych }\end{array}$ & $\begin{array}{l}\text { Dalsze głębsze } \\
\text { poznawanie } \\
\text { środowiska } \\
\text { przyrodniczego } \\
\text { i dostrzeganie } \\
\text { skutków jego de- } \\
\text { gradacji poprzez } \\
\text { różne czynniki, } \\
\text { w tym prace } \\
\text { człowieka. } \\
\text { Kształtowanie } \\
\text { postaw prośrodo- } \\
\text { wiskowych po- } \\
\text { przez wdrażanie } \\
\text { do segregowania } \\
\text { odpadów. } \\
\text { Kształtowanie } \\
\text { postaw prośrodo- } \\
\text { wiskowych po- } \\
\text { przez wdrażanie } \\
\text { do oszczędności } \\
\text { w zużyciu energii } \\
\text { i wody }\end{array}$ \\
\hline 4. & $\begin{array}{l}\text { Ciąg dalszy } \\
\text { kształcenia } \\
\text { ogólnego } \\
\text { podstawo- } \\
\text { wego - naucza- } \\
\text { nie blokowe } \\
\text { i przedmiotowe } \\
\text { na poziomie } \\
\text { elementarnym }\end{array}$ & $10-16$ & $\begin{array}{l}\text { Edukacja środowiskowa na } \\
\text { kolejnych podstawowych } \\
\text { etapach kształcenia ogólnego }\end{array}$ & \multirow[t]{2}{*}{$\begin{array}{l}\text { Wysoka świado- } \\
\text { mość ekologiczna, } \\
\text { czyli pozytywne } \\
\text { postawy i zacho- } \\
\text { wania w stosunku } \\
\text { do przyrody jako } \\
\text { wynik edukacji } \\
\text { środowiskowej }\end{array}$} \\
\hline 5. & $\begin{array}{l}\text { Dopełniające } \\
\text { kształcenie } \\
\text { ogólne (licea } \\
\text { ogólnokształ- } \\
\text { cące i szkoły } \\
\text { zawodowe) }\end{array}$ & $16-19$ & $\begin{array}{l}\text { Edukacja środowiskowa na } \\
\text { licealnym etapie kształcenia } \\
\text { ogólnego }\end{array}$ & \\
\hline
\end{tabular}




\begin{tabular}{|c|c|c|c|c|}
\hline Lp. & $\begin{array}{l}\text { Okres rozwo- } \\
\text { jowy podmiotu } \\
\text { uczącego }\end{array}$ & $\begin{array}{l}\text { Lata } \\
\text { życia }\end{array}$ & $\begin{array}{l}\text { Właściwości działań } \\
\text { pedagogicznych }\end{array}$ & $\begin{array}{l}\text { Wyniki w powią- } \\
\text { zaniu z pracą }\end{array}$ \\
\hline 6. & $\begin{array}{l}\text { Kształcenie } \\
\text { o charakterze } \\
\text { zawodowym } \\
\text { (zasadnicze } \\
\text { szkoły zawo- } \\
\text { dowe, tech- } \\
\text { nika, szkoły } \\
\text { policealne, } \\
\text { szkoły wyższe) }\end{array}$ & $16-24$ & $\begin{array}{l}\text { Edukacja środowiskowa na } \\
\text { ponadgimnazjalnych etapach } \\
\text { kształcenia zawodowego }\end{array}$ & $\begin{array}{l}\text { Wysoka świado- } \\
\text { mość ekologiczna, } \\
\text { czyli pozytywne } \\
\text { postawy i zacho- } \\
\text { wania w nauce } \\
\text { zawodu jako } \\
\text { wyraz stosunku } \\
\text { do przyrody } \\
\text { i wynik edukacji } \\
\text { środowiskowej. } \\
\text { Kształtowanie } \\
\text { postaw prośro- } \\
\text { dowiskowych } \\
\text { w nauczanych } \\
\text { zawodach. } \\
\text { Kształtowanie } \\
\text { umiejętności } \\
\text { i nawyków w za- } \\
\text { gospodarowywa- } \\
\text { niu i sortowaniu } \\
\text { odpadów surow- } \\
\text { cowych i po- } \\
\text { produkcyjnych } \\
\text { oraz uczynienie } \\
\text { ich elementem } \\
\text { kwalifikacji } \\
\text { i kompetencji } \\
\text { zawodowych }\end{array}$ \\
\hline
\end{tabular}




\begin{tabular}{|l|l|l|l|l|}
\hline Lp. & $\begin{array}{l}\text { Okres rozwo- } \\
\text { jowy podmiotu } \\
\text { uczącego }\end{array}$ & $\begin{array}{l}\text { Lata } \\
\text { życia }\end{array}$ & $\begin{array}{l}\text { Właściwości działań } \\
\text { pedagogicznych }\end{array}$ & $\begin{array}{l}\text { Wyniki w powią- } \\
\text { zaniu z pracą }\end{array}$ \\
\hline $\begin{array}{l}\text { Kształcenie } \\
\text { pracy zawo- } \\
\text { dowej w róż- } \\
\text { nych formach } \\
\text { i postaciach } \\
\text { ze względu } \\
\text { na jego } \\
\text { wymagania }\end{array}$ & $25-65$ & $\begin{array}{l}\text { Edukacja środowiskowa } \\
\text { w okresie aktywności zawo- } \\
\text { dowej, kształtująca prośro- } \\
\text { dowiskowe postawy oraz styl } \\
\text { życia i wypoczynku w czy- } \\
\text { stym otoczeniu w procesach } \\
\text { pracy }\end{array}$ & $\begin{array}{l}\text { Zarządzanie } \\
\text { przez ekologię, } \\
\text { upowszechnia- } \\
\text { nie organizacji } \\
\text { pracy opartej na } \\
\text { wysokiej świado- } \\
\text { mości ekologicz- } \\
\text { nej, wyrażonej } \\
\text { minimalizowa- } \\
\text { niem odpadów, } \\
\text { zużycia energii } \\
\text { oraz stosowaniem } \\
\text { technicznych } \\
\text { i technologicz- } \\
\text { nych rozwiązań } \\
\text { prośrodowisko- } \\
\text { wych, wykorzy- } \\
\text { stujących postęp } \\
\text { naukowy i cywi- } \\
\text { lizacyjny w tym } \\
\text { obszarze (ko- } \\
\text { lektory energii } \\
\text { słonecznej itp.) }\end{array}$ \\
\hline
\end{tabular}

Źródło: opracowanie własne.

Treść tabeli 4. pokazuje, że stan środowiska przyrodniczego jest konsekwencją kształtowania stosunku człowieka do przyrody. Wpisuje się on w problematykę wychowawczą, a ta determinuje postawy człowieka wobec przyrody - potrzebę jej ochrony oraz dbałości o nią. Przewija się zatem ona przez całe życie człowieka, stosunek do przyrody kształtowany jest już w domu rodzinnym, następnie w kolejnych środowiskach, tj. edukacyjnych oraz zawodowych, a także podczas spędzania czasu wolnego. Pokazany model wpisuje się w tematykę nie tylko wychowawczą, ale i pracy. Interesuje on pedagoga pracy, bo pokazuje, jak przyroda towarzyszy człowiekowi przez jego całe życie i jak je wypełnia. To uzasadnia potrzebę kształtowania stosunku człowieka do przyrody, konieczność jej ochrony, a uświadomienie tegoż zadania jest następstwem promocji postaw i zachowań prośrodowiskowych. Tylko takie całościowe podejście do zagadnienia środowiska przyrodniczego, rozumienia jego problemów i potrzeby jego kształtowania może stać się gwarantem 
podtrzymania stanu środowiska przyrodniczego i przekazania go następnym pokoleniom w stanie co najmniej przejętym przez dane pokolenie. Owo podejście zapewnia przetrwanie wartości środowiska przyrodniczego przyjętych przez kolejne pokolenia. Wpisuje się ono w wychowawcze konteksty, dowodząc zasadności ujęcia problematyki środowiska przyrodniczego w kompleksie nauk pedagogicznych wraz z pedagogiką pracy oraz naukami o pracy, a przez to nadania mu holistycznego wymiaru, co stanowi treść kolejnych rozważań.

Środowisko przyrodnicze obszarem zainteresowań pedagogiki pracy, innych nauk pedagogicznych oraz nauk o pracy

XXI wiek to czas wielu wyzwań dla człowieka. Jednym z nich stają się problemy naszej planety i jej alarmujący stan ze względu na wielość zagrożeń cywilizacyjnych. Jest to następstwem postępu technicznego, dokonującego się dzięki człowiekowi i jego twórczej działalności. Ta nie może jednak ponad miarę eksploatować zasobów złóż mineralnych ani emitować spalin do środowiska przyrodniczego tylko w celu maksymalizacji zysku (Nowacki 1964, s. 39-62). Tadeusz W. Nowacki na początku nowego tysiąclecia w swej koncepcji układu i opisu elementów procesu pracy (zob. rysunek 1.) wyodrębnił kategorię zagospodarowania odpadów w procesie pracy. W ten sposób stworzył podwaliny pod dokument Komisji Europejskiej Europa 2020. Strategia na rzecz inteligentnego i zrównoważonego rozwoju sprzyjajacego włączaniu społeczeństwa (Komunikat Komisji Europejskiej „Europa 2020... 2010), która promuje m.in. zrównoważony rozwój. Interesuje on również papieża Franciszka, który na kanwie nauki społecznej Kościoła nie tylko przywołuje w pieśni Świętego Franciszka z Asyżu opis matki ziemi, która „nas żywi i chowa” (Franciszek 2015, s. 4), ale też nawiązuje do wcześniejszych papieskich encyklik, pokazujących wiele nie do końca przemyślanych zachowań człowieka, żądnego sławy, a przez to doprowadzającego do współczesnych katastrof ekologicznych. Dlatego najwyższy czas, aby zrekonstruować model zaprojektowany przez Zygmunta Wiatrowskiego w 1985 roku, a niezweryfikowany w jego nowszej książce Podstawy pedagogiki pracy, wydanej po raz pierwszy w roku 1994 i wznawianej do roku 2005, w miejsce Pedagogiki pracy w zarysie (1985). Pomimo nowych treści włączanych przez dwadzieścia lat do pedagogiki pracy model kompleksu nauk pedagogicznych z usytuowaniem w nim pedagogiki pracy nie uległ zmianie (zob. rysunek 2.). 


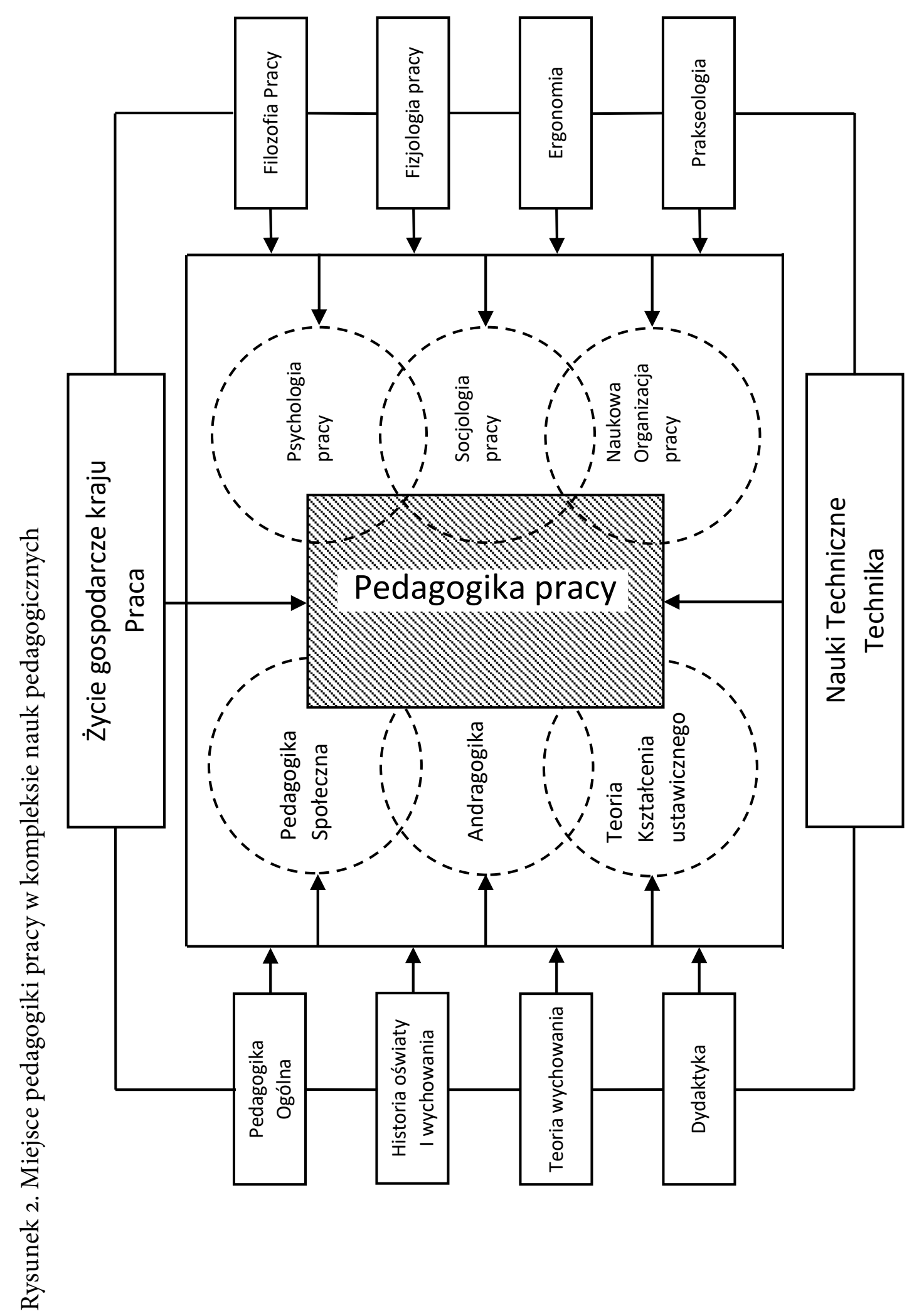


Treść rysunku 2. nie ujmuje pedagogiki ekologicznej, dlatego nie zawiera analizy proekologicznego nastawienia nauk technicznych, które pozwoliłyby na uczynienie pracy człowieka jak najmniej uciążliwą zarówno dla niego samego, jak i otoczenia, czyli środowiska przyrodniczego. Zasadna jest więc jego rekonstrukcja. Nowy model pedagogiki pracy w kompleksie nauk pedagogicznych, a także nauk o pracy, musi uwzględnić potrzeby współczesnego świata i określić w nim miejsce środowiska przyrodniczego, niezbędnego do życia wszystkich organizmów, a zatem i człowieka. Ten ostatni powinien być świadomy swych działań i zachowań w każdej sytuacji życiowej, tj. nauki, zabawy, w tym korzystania z uroków i osobliwości przyrody - zarówno podczas spędzania czasu wolnego, jak i pracy zawodowej, starając się dążyć do promowania i prezentowania postaw czy zachowań przyjaznych środowisku przyrodniczemu ze względu na walory i wartości przyrody oraz potrzebę ich zachowania dla kolejnych pokoleń. Podstawa rekonstrukcji wciąż obowiązującego modelu nauk pedagogicznych, z pedagogiką pracy włącznie, zawiera się w pytaniu: czym jest pedagogika ekologiczna i jak jest rozumiana? Jedną z odpowiedzi znajdujemy u Wincentego Okonia, który pod koniec XX wieku uważał, że pedagogika ekologiczna to nie "nowa dyscyplina pedagogiczna, lecz swoiste ukierunkowanie myślenia pedagogicznego; jego przedmiotem jest obszar graniczny teoretycznego myślenia i działania praktycznego, na którym krzyżują się problemy korzystnych dla życia warunków środowiskowych i problemy wychowawcze, [...] wyznaczające sumę celów, wiadomości naukowych i środków sprzyjających wychowaniu środowiskowemu i życiu w naszym zagrożonym świecie" (Okoń 1992, s. 152). Dalej konkludując i powołując się na ogromną popularność pedagogiki ekologicznej w cywilizacjach zachodnich, pisze, że „zawdzięcza [ją] przeciwstawianiu się koncepcjom fazowego rozwoju człowieka, zajmujących się jednostką ludzką w izolacji od zewnętrznych warunków jej rozwoju" i pomijających, czyli niedostrzegających, „otoczenia życia człowieka i jego walorów” (tamże, s. 152). Wątek ten podejmuje również Agnieszka Gromkowska-Melosik, która wprowadza pojęcie etyki ekologicznej, tożsame dla niej z ekoetyką i rozumiane ,jako moralne postępowanie człowieka wobec przyrody" (Gromkowska-Melosik 2006, s. 433) z uwagi na:

"- uznanie ograniczoności zasobów naturalnych ziemi,

- traktowanie człowieka jako jednego z elementów przyrody, poprzez odrzucenie antropocentryzmu i zastąpienie go ekocentryzmem,

- dążenie do przekazania niezniszczonego środowiska naturalnego kolejnym pokoleniom,

- optymalną ingerencję człowieka w środowisko naturalne,

- rozwój świadomości ekologicznej" (Kośmicki 1992, s. 68-69).

Wyeksponowany androcendryzm, wyrażony w destruktywnych zachowaniach i działaniach, Agnieszka Gromkowska-Melosik ukazuje jako charakterystyczny dla typowo męskich cech, takich jak: racjonalność, orientacja na dominację, konkurencyjność, indywidualność, których dominacja omal nie doprowadziła do prawie całkowitej zagłady ekosystemu (Gromkowska-Melosik 2006, s. 433). Żądza zysku za wszelką cenę, 
kosztem środowiska przyrodniczego i upowszechniania zachowań niezgodnych z etyką ekologiczną, spowodowała powstanie wielu ruchów ekologicznych, w które - na zasadzie przeciwieństwa - zaangażowały się kobiety, nazywając swój ruch ekofeminizmem (tamże, s. 433-434). Jego współczesne realia wpisują się w aktualne trendy promocji i zatrudniania kobiet na coraz wyższych, bardziej eksponowanych stanowiskach, co pozwala mniemać, że ta aktywność zawodowa kobiet nie pozostanie bez wpływu na stan środowiska przyrodniczego, m.in. za sprawą ich wrażliwości i estetyki, pragnienia, by zawsze żyć w ładzie i porządku i do nich dążyć. Feministyczny wątek współczesnej pracy, czyli obejmowanie coraz wyższych stanowisk przez kobiety, wpisuje się również $\mathrm{w}$ promocję trendów pracy skierowanych ku środowisku przyrodniczemu i postrzeganiu oraz promowaniu jego walorów oraz wartości. Trend ten jest możliwy dzięki zdecydowanie większej wrażliwości kobiet na piękno, na tę uniwersalistyczną wartość, pożądaną w rozwoju postaw prośrodowiskowych i dążeniu do utrzymania stanu środowiska przyrodniczego w postaci co najmniej zastanej, czyli niezniszczonej, kolejnym pokoleniom. Dlatego zarówno pracownicy, jak i pracodawcy - bez względu na płeć - powinni być świadomi swych działań i promocji postaw na rzecz ekosystemu oraz jego ochrony, które wyznaczają zadania edukacji nie tylko szkolnej, ale i pozaszkolnej. W tym kontekście współczesna klasyfikacja nauk pedagogicznych nie może pominąć pedagogiki ekologicznej. Powinna ona pomóc w ukształtowaniu postaw proekologicznych i promocji zachowań wpisanych w treść raportu Europa 2020... (2010), rozumianego jako strategia na rzecz inteligentnego i zrównoważonego rozwoju. W tę pierwszą wpisuje się inteligentny rozwój gospodarki, oparty na wiedzy i innowacji, który wymagać będzie nowych zawodów związanych ze środowiskiem naturalnym i zagospodarowaniem odpadów, generujących nowe miejsca pracy (Baraniak 2016, s. 36). Natomiast w rozwój zrównoważony, rozumiany jako wspieranie gospodarki poprzez efektywniejsze wykorzystywanie zasobów, bardziej przyjazne środowisku przyrodniczemu (Sławińska 2013), wpisują się tzw. poletka ekologiczne do wykorzystywania energii słonecznej, dachowe panele słoneczne czy wreszcie energia wiatrowa. Są to działania, których wynikiem powinno stać się ograniczenie w porównaniu z 1990 roku o 20\% emisji dwutlenku węgla i zwiększenie o 30\% odnawialnych źródeł energii, co będzie również szansą na wprowadzanie na rynek pracy nowych zawodów o profilu prośrodowiskowym. To kolejny przykład pokazujący przyszłość pedagogiki ekologicznej i jej miejsce w całościowym kompleksie nauk pedagogicznych, jak również w subdyscyplinarnych obszarach, w szczególności pedagogice pracy. Dążenie do nowych rozwiązań technologicznych w procesie pracy to nie tylko korzyści ekonomiczne, ale też tworzenie bardziej przyjaznego środowiska nie tylko dla człowieka (Nowacki 1980, s. 46-50), ale także dla przyrody. Wymaga to należytego zagospodarowywania odpadów, zgodnie z koncepcjami Tadeusza W. Nowackiego (2004, s. 24-31) pokazującymi, że pedagogika pracy nie może pozostać obojętna ekologii, a pedagogika ekologiczna wraz z towarzyszącymi jej naukami powinna być wpisana w sposób naukowy w kompleks nauk o pracy, co ilustruje rysunek 3., ukazujący pedagogikę pracy jako subdyscyplinę pedagogiczną i naukę o pracy wzbogaconą o problemy prośrodowiskowe. 


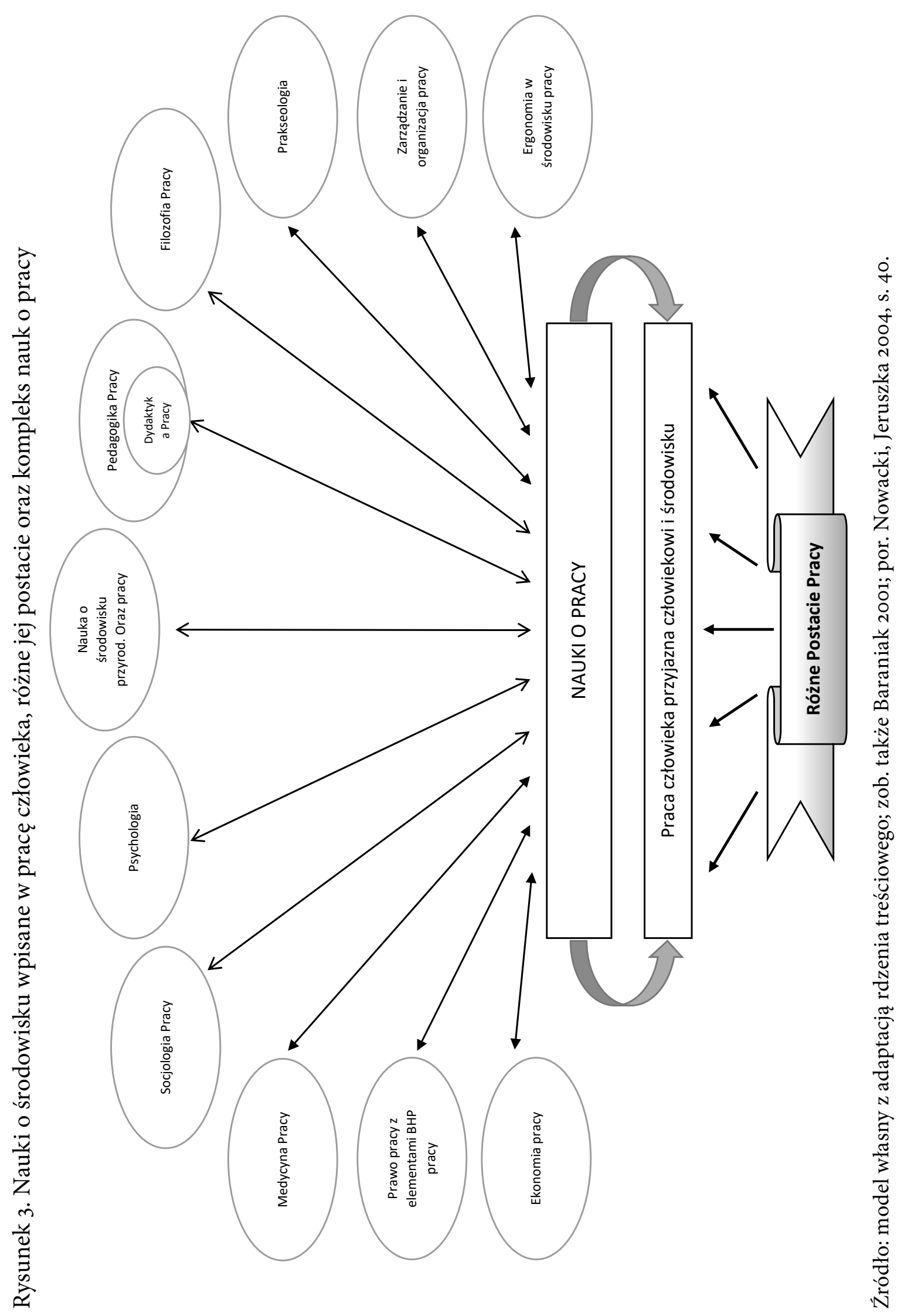


W nowelizowany model wpisane zostały nauki o środowisku przyrodniczym. Ich treść powinna zawrzeć się we współczesnej problematyce badawczej pracy (Baraniak 2008), a także w nowych, ważnych kontekstach pracy, jak doradztwo zawodowe i personalne (Ludwiczyński 2006), z jednym $\mathrm{z}$ aktualnie ważniejszych zagadnień dla pracownika i pracodawcy, jakim są zasoby ludzkie we współczesnej pracy (zob. rysunek 4.).

Rysunek 4. Składniki otoczenia pracy w funkcji kapitału ludzkiego

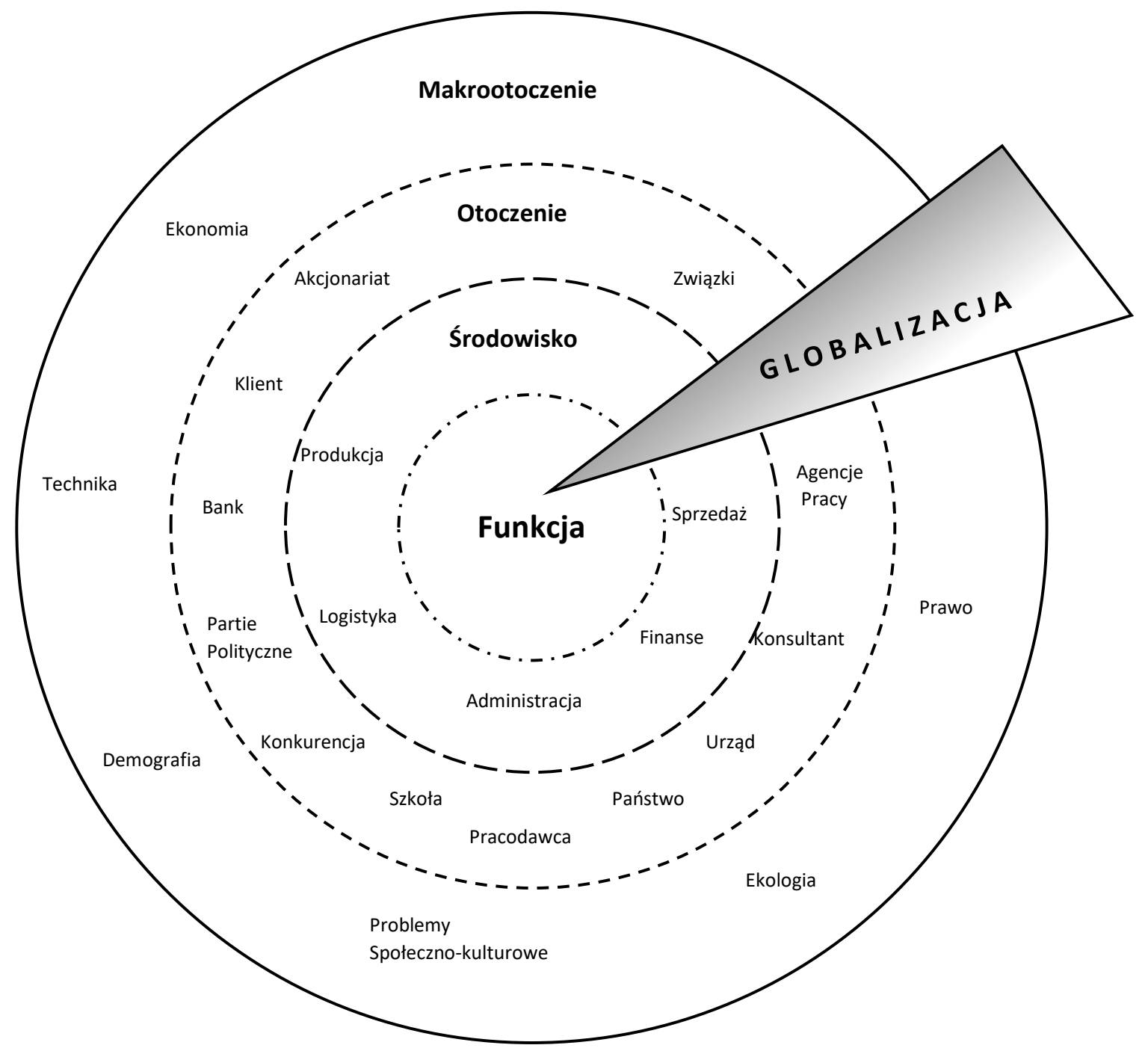

Źródło: Pocztowski 2013, s. 46.

Usytuowane w interesujących obszarach badawczych pedagogiki pracy treści ekologiczne dowodzą, że dotychczas niedostrzegana i niedoceniana ekologia, $w$ tym pracy (Pocztowski 2013), nie może pozostać niedostrzeżona i niedoceniona, ponieważ jest przedmiotem swoistego zainteresowania, analogicznie do pracy ludzkiej. To uzasadnia wpisanie jej w aktualną problematykę pedagogiki pracy i jednego 
z ważnych jej zadań, jakim pozostaje wychowanie, zgodne z przedmiotem badań tej subdyscypliny, który nie może - analogicznie jak kompleks nauk o pracy - pominąć środowiska przyrodniczego skorelowanego z pedagogiką ekologiczną. Tę nową propozycję, rozszerzoną o pedagogikę ekologiczną, w grupie nauk pedagogicznych ilustruje rysunek 5 .

Rysunek 5. Pedagogika pracy a inne nauki pedagogiczne wraz z pedagogiką ekologiczną

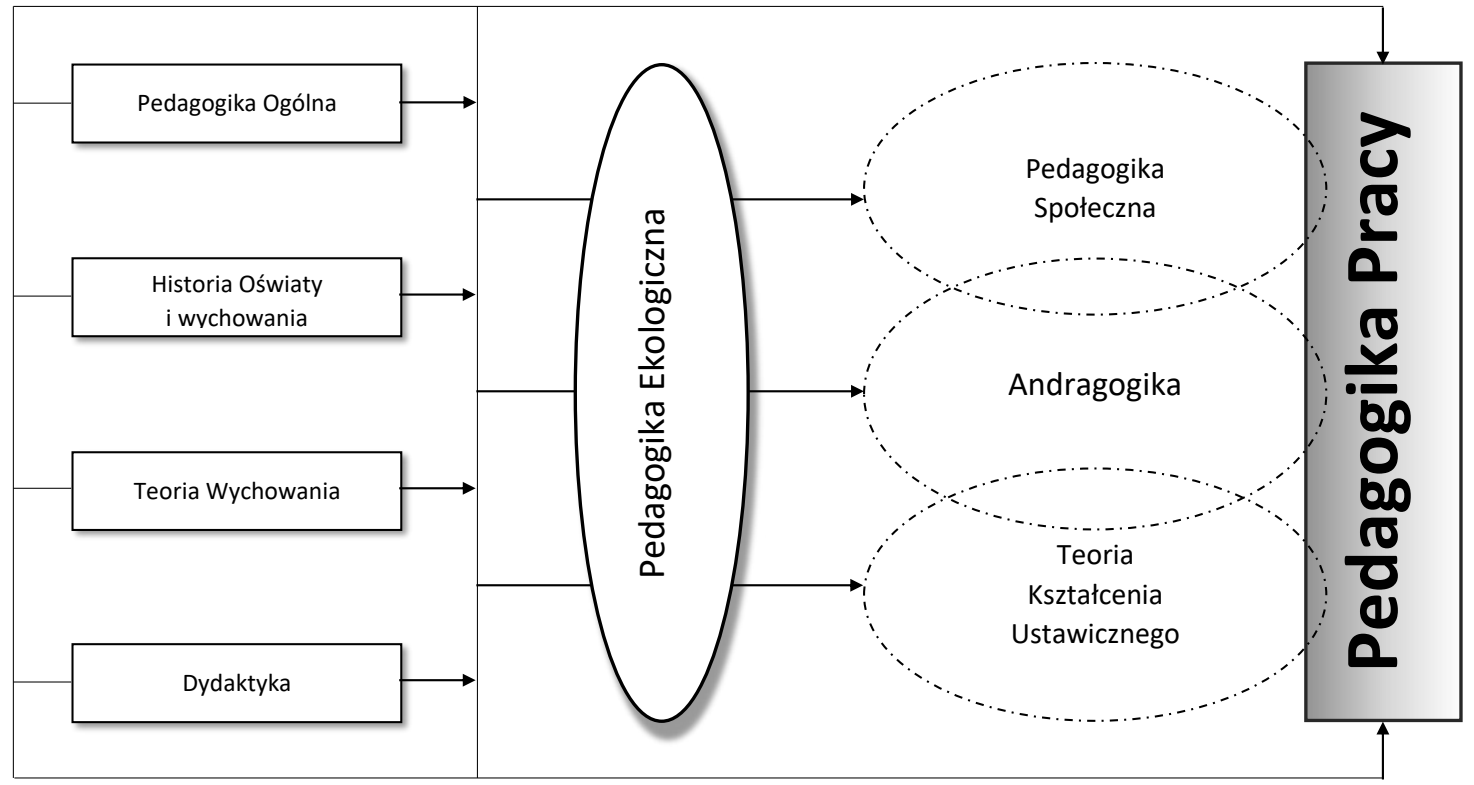

Źródło: Wiatrowski 2005, s. 47 - z własną adaptacją dla potrzeb edukacji prośrodowiskowej.

Problem wychowania, będący domeną nauk pedagogicznych, wymaga interdyscyplinarnego podejścia (zob. rysunek 5.), które nie może pominąć potrzeby kształtowania świadomości ekologicznej społeczeństwa. Symbioza człowieka ze środowiskiem przyrodniczym nakłada na edukację potrzebę kształtowania postaw prośrodowiskowych od najmłodszych lat i kontynuowania tego ze zdwojoną energią w czasie dalszej edukacji i towarzyszącej jej pracy zawodowej. Jej różne postacie wraz ze stosowaniem bardzo odmiennych surowców i materiałów pomocniczych, w tym energetycznych, wymagają spojrzenia na procesy technologiczne pod kątem promocji w nich surowców biodegradowalnych, technologii energooszczędnych, tj. przyjaznych środowisku przyrodniczemu, oraz należytego zagospodarowania odpadów i ścieków poprodukcyjnych. Jest to zakres działań edukacji zarówno szkolnej, jak i pozaszkolnej oraz incydentalnej - ukierunkowanej na pracownika, pracodawcę, a także każdego obywatela oczekującego życia $\mathrm{w}$ przyjaznym i czystym otoczeniu - prowadzonych w oparciu o odpowiednio przygotowane oferty programowe. Udział tych działań w kształtowaniu postaw wpisuje się w prośrodowiskową organizację bardziej przyjaznych dla człowieka środowisk pracy, co nie może być pominięte przez projektanta czy konstuktora. 
Przekonuje o tym najstarszy dokument zawierający zasady poprawnego projektowania. Za taki uznaję pracę Witruwiusza $O$ architekturze ksiąg dziesięć z I wieku p.n.e., opisującą jej przymioty przyjazne człowiekowi. Są one wciąż aktualne, co potwierdzają przemyślenia Stanisława J. Cieślakowskiego i Tomasza Kupidury (2003) o potrzebie dostrzegania fizycznych i psychicznych oczekiwań człowieka od procesu pracy. Przyczyniają się one nie tylko do zwiększenia wydajności pracy, zmniejszenia liczby braków i pomyłek popełnianych przez człowieka, a w ślad za tym reklamacji wadliwych produktów, lepszego wykorzystania czasu pracy, ale i do poprawienia warunków pracy, zwiększenia jej bezpieczeństwa, zmniejszenia wypadkowości w pracy, eliminacji niebezpiecznych i szkodliwych czynników dla zdrowia człowieka, a także dla otoczenia, czyli środowiska przyrodniczego (uzup. Baraniak 2015; także Baraniak 2016 a i b), wreszcie zwiększenia satysfakcji z pracy i poprawienia samopoczucia pracowników (Cieślakowski, Kupidura 2003). Powyższe problemy to kolejne zadanie edukacyjne, ważne w kontekście zagrożeń $\mathrm{z}$ tytułu bagatelizowania problemów prośrodowiskowych, realizowane w różnym czasie i miejscach, na co pozwala edukacja permanentna z jej modelem autorstwa Zygmunta Wiatrowskiego (2005, s. 357). Podobnie jak nauki pedagogiczne i nauki o pracy wymaga ona rekonstrukcji, w kontekście chociażby zapowiadanej reformy strukturalnej systemu oświaty, a także wpisania treści dotyczących środowiska przyrodniczego i potrzeby jego chronienia $\mathrm{w}$ zakres wykształcenia formalnego oraz prośrodowiskowego trendu w edukacji pozaformalnej, skierowanej do osób dorosłych, w tym pracowników, pracodawców oraz każdego obywatela korzystającego w różny sposób z zasobów przyrody. Powszechnie uważa się, że za aktualny stan środowiska odpowiedzialni są pracodawcy oraz prowadzący gospodarstwa domowe, a także obywatele korzystający z zasobów przyrody. Dlatego celowe jest kształtowanie wrażliwości każdego człowieka na przyrodę i jej nieniszczenie. Zatem dzięki odpowiednio ukierunkowanym działaniom edukacyjnym, nie jednorazowym, ale długofalowym, istnieje szansa na przetrwanie przyrody i jej walorów, w czym pomocna będzie kształtowana świadomość ekologiczna wszystkich grup społecznych, począwszy od członków rodziny, poprzez uczniów, aż po osoby dorosłe pełniące różne funkcje społeczne. To ważne zadanie, jakie staje przed edukacją, zarówno formalną, jak i nieformalną oraz incydentalną.

\section{Podsumowanie}

Podjęte rozważania ukazują potrzebę nieustannego weryfikowania zakresu edukacji ekologicznej, czego wyrazem jest wpisanie w kompleks nauk pedagogicznych i nauk o pracy problemów środowiska przyrodniczego z usytuowaną $\mathrm{w}$ nim pedagogiką ekologiczną, kształtującą świadomość ekologiczną społeczeństwa, począwszy od dzieci przez młodzież po osoby dorosłe z pracownikami i obywatelami włącznie. Owo rozwiązanie nada edukacji ekologicznej wymiar całożyciowy, dzięki czemu możliwe staną się oddziaływania wychowawcze promujące przyrodę i jej wartości 
różnymi kanałami, w tym poprzez edukację medialną dostępną dla każdego obywatela. W ten sposób edukacja wpisze się w kolejne współczesne wyzwanie, to jest kształtowanie pożądanych społecznie postaw, w tym w organizacji pracy, a nie tylko dążenie do jej ekonomizacji. Tylko wówczas jeszcze niedostrzegana i niedoceniana ekologia pracy (Pocztowski 2013, s. 46-50) ma szansę wpisać się w ochronę przyrody. Dlatego należy nieustannie dążyć do kształtowania wrażliwości na środowisko przyrodnicze zamiast jego niszczenia dzięki eliminowaniu nagannych zachowań człowieka, w tym pracującego, wobec środowiska. One pozostają wciąż w kręgu zainteresowania pedagogów, także pracy. Powinno się eksponować rolę edukacji ukierunkowanej na kształtowanie świadomości ekologicznej, dzięki której środowisko przyrodnicze może doczekać się lepszego rozumienia. Tego zadania edukacyjnego nie mogą pominąć szeroko rozumiane nauki pedagogiczne wraz z modelem edukacji permanentnej (Wiatrowski 2005, s. 357), a dopełniające również struktury nauk o pracy. Wpisane w nie modele edukacji zawodowej ukazują wielość edukacyjnych form przydatnych w upowszechnianiu świadomości ekologicznej różnych grup społecznych, w tym uczących się zawodu i pracujących, z zatem niezbędnych dla pól pedagogicznych i nauk o pracy.

\section{Bibliografia}

Baraniak B. (2015b). Człowiek $w$ procesie pracy $z$ perspektywy kierowania i zarzqdzania. W: Baraniak B., Galas B., Krajewska B., Janiec S., Babicki Z., Nawrat D. Człowiek i jego współczesne problemy kontekstami pedagogiki pracy i pedagogiki społecznej. Warszawa: Wydawnictwo UKSW.

Baraniak B. (2008). Edukacja w przygotowaniu człowieka do pracy zawodowej. Warszawa: Instytut Badań Edukacyjnych.

Baraniak B. (2016). Gospodarka - zawody - praca problemami wpisanymi w poradnictwo zawodowe promujące środowisko przyrodnicze. W: Baraniak B. i in. (red.). Poradnictwo zawodowe w ksztaltowaniu świadomości ekologicznej społeczeństwa. Od teorii do praktyki. Warszawa: Wydawnictwo UKSW.

Baraniak B. (2015a). Praca ważna kategoria naukowa (poznawcza) $i$ badawcza pedagogiki pracy. W: Baraniak B., Wolter E., Sałyga M., Kulpa-Puczyńska A., Brzeziński J., Janiec S. Edukacja i praca człowieka implikacjami dla pedagogiki pracy i pedagogiki społecznej. Warszawa: Wydawnictwo UKSW.

Baraniak B. (2001). Programy kształcenia zawodowego: teoria, metodologia, aplikacje. Warszawa: Instytut Badań Edukacyjnych.

Baraniak B. (2016). Teoria poradnictwa zawodowego w strukturze treściowej pedagogiki pracy - subdyscypliny naukowej wrażliwej na środowisko przyrodnicze. W: Baraniak B. i in. (red.). Poradnictwo zawodowe w ksztattowaniu świadomości ekologicznej społeczeństwa. Od teorii do praktyki. Warszawa: Wydawnictwo UKSW. 
Baraniak B. (2010 wyd. I, 2013 wyd. II). Współczesna pedagogika pracy z perspektywy edukacji, pracy i badań. Warszawa: Wydawnictwo UKSW.

Baraniak B., Figurski J. (2004). Praca doradcy zawodowego w placówkach oświatowych. W: Bednarczyk H., Figurski J., Żurek M. (red.). Pedagogika pracy. Doradztwo zawodowe. Warszawa: Wyższa Szkoła Pedagogiczna ZNP, Radom: Instytut Technologii Eksploatacji.

Bednarczyk H., Symela K. (2002). Radomskie spotkania $z$ Profesorem Tadeuszem W. Nowackim. „Pedagogika Pracy”, nr 52.

Borkowska S. (2006). Motywacja i motywowanie. W: Król H., Ludwiczyński A. (red.). Zarzadzanie zasobami ludzkimi. Tworzenie kapitału organizacji. Warszawa: Wydawnictwo Naukowe PWN.

Braun S., Bauer K. (1999). Ochrona środowiska w zarządzaniu przedsiębiorstwem. Krosno: Fundacja Centrum Edukacji Ekologicznej Wsi w Krośnie.

Cieślakowski S., Kupidura T. (2003). Nauczanie ergonomii a organizacja bezpiecznych warunków pracy. „Pedagogika Pracy”, nr 43.

Denek K. (2008). Poza ławka szkolną. Żary: Wydawnictwo Naukowe Łużyckiej Wyższej Szkoły Ekonomicznej.

Franciszek (2015). Encyklika Laudato si'. Warszawa.

Furmanek W. (2015). Pedagogika wobec wyzwań wspótczesności. „Annales UMCS”, sectio J, Paedagogia - Psychologia, t. XXXVI, 1-2.

Gromkowska-Melosik A. (2006). Pedagogika ekologiczna. W: Kwieciński Z., Śliwerski B. (red.). Pedagogika. Warszawa: Wydawnictwo Naukowe PWN.

Kacak I., Skoczylas K. (2013). Badania świadomości prośrodowiskowej pracowników MSP sektora metalowego. „Edukacja Ustawiczna Dorosłych”, nr 4.

Kargulowa A. (2004). O teorii i praktyce poradnictwa. Warszawa: Wydawnictwo Naukowe PWN.

Keating D.P. (1998). Human development in the learninig society. W: Hargreaves A., Lieberman A., Fullan M., Hopkins D. (red.). International handbook of educational change, cz. 2. Dordrecht: Springer.

Komunikat Komisji Europejskiej „Europa 2020. Strategia na rzecz inteligentnego i zrównoważonego rozwoju sprzyjającego włączaniu społeczeństwa" (2010). Bruksela, dostępny na: http://ec.europa.eu/europa/strategia/index.pl.http (otwarty 15.01.2015).

Kośmicki E. (1992). Podstawowe problemy etyki ekologicznej. W: Andrzejewski B. (red.). Humanistyka i ekologia. Poznań: Fundacja Warta.

Naisbitt W.J. (1997). Megatrendy. Poznań: Zysk i S-ka.

Nowacki T. (2004). Leksykon pedagogiki pracy. Radom: Instytut Technologii Eksploatacji.

Nowacki T. (1976). Metodologia pedagogiki pracy. Warszawa: Wydawnictwa Szkolne i Pedagogiczne.

Nowacki T. (1973). Organizacja i zadania Instytutu Kształcenia Zawodowego. Warszawa. 
Nowacki T. (1964). Wychowanie a cywilizacja techniczna. Warszawa: Książka i Wiedza.

Nowacki T. (1972). Zagadnienia poradnictwa i zawodoznawstwa. „Nauczyciel i Wychowanie", nr 4.

Nowacki T. (1999 wyd. I, 2001 wyd. II, 2003 wyd. III). Zawodoznawstwo. Radom: Instytut Technologii Eksploatacji.

Nowacki T., Jeruszka U. (2004). Podstawy dydaktyki pracy. Warszawa: Wydawnictwo Wyższej Szkoły Pedagogicznej Towarzystwa Wiedzy Powszechnej.

Nowacki T., Korabiowska-Nowacka K., Baraniak B. (200o). Nowy słownik pedagogiki pracy. Warszawa.

Obwieszczenie Marszałka Sejmu Rzeczypospolitej Polskiej z dnia 9 kwietnia 2008 r. $w$ sprawie ogłoszenia jednolitego tekstu ustawy o promocji zatrudnienia $i$ instytucjach rynku pracy. Dz.U. 2008, nr 69, poz. 415.

Okoń W. (1992). Słownik pedagogiczny. Warszawa: Wydawnictwo Wyższej Szkoły Pedagogicznej Towarzystwa Wiedzy Powszechnej.

Parzęcki R. (2003). Plany edukacyjno-zawodowe młodzieży w stadium eksploracji. Zamierzenia - wybory - relacje. Włocławek: Wyższa Szkoła Humanistyczno-Ekonomiczna we Włocławku.

Pocztowski A. (2013). Zarzadzanie zasobami ludzkimi. Warszawa: Polskie Wydawnictwo Ekonomiczne.

Rozporzadzenie Ministra Pracy i Polityki Społecznej z dnia 7 sierpnia 2014 r. w sprawie klasyfikacji zawodów i specjalności na potrzeby rynku pracy oraz zakresu jej stosowania. Dz.U. z dn. 28.08.2014 r., poz. 1145 - rozporządzenie weszło w życie $\mathrm{z}$ dniem 1.01.2015 r.

Skills for Green Jobs (2010). Europass synthesis report. Publication office of the European Union. Luxemburg.

Sławińska K. (2013). Podnoszenie świadomości ekologicznej i z zakresu prawa pracy u osób o specjalnych potrzebach edukacyjnych. W: Badowska A. (red.). Ochrona pracy jako przedmiot badań pedagogiki pracy. Radom: Instytut Technologii Eksploatacji.

Sławińska K., Symela K. (2014). Ochrona środowiska w projektach edukacyjnych. „Edukacja Ustawiczna Dorosłych”, nr 3.

Toffler A., Toffler H. (1998). Budowa nowej cywilizacji. Polityka trzeciejfali. Poznań: Zysk i S-ka.

Toffler A. (1974). Szok przyszłości. Poznań: Kurpisz.

Toffler A. (2006). Trzecia fala. Poznań: Kurpisz.

Uchwała nr 162 Rady Ministrów z dnia 15 czerwca 1972 r. w sprawie utworzenia Instytutu Kształcenia Zawodowego. „Monitor Polski”, nr 32.

Ustawa $z$ dnia 27 kwietnia 2001 r. o odpadach. Dz.U. 2001, nr 62, poz. 628.

Wiatrowski Z. (1980 wyd. I; 1985 wyd. II). Pedagogika pracy w zarysie. Bydgoszcz: WSP, Warszawa: Wydawnictwo Naukowe PWN.

Wiatrowski Z. (2005 wyd. IV). Podstawy pedagogiki pracy. Bydgoszcz: WSP. 
Wojtasik B. (2001). Podejmowanie decyzji zawodowych przez młodzież i osoby dorosłe w nowej rzeczywistości społeczno-politycznej. Wrocław: Instytut Pedagogiki Uniwersytetu Wrocławskiego.

Wojtasik B. (red.). (1998). Z podstaw poradoznawstwa. Wrocław: Wydawnictwo Uniwersytetu Wrocławskiego.

Vitruvius P.M., Verfasste mit „De architectura libri decem”, dostępny na: www.empik.com/zehn-buecher-architektur-pollio-marcus-vitruvius (otwarty 1.06.2015).

\section{NATURAL ENVIRONMENT AS A CURRENT PROBLEM OF BOTH PEDAGOGY STUDIES AND PEDAGOGY OF WORK, INCLUDING STUDIES OF WORK}

Summary: So far unappreciated, even unnoticed by most work studies of work, natural environment is presently experiencing a renaissance, which is expressed in the search for more eco-friendly methods of work, the wider application of unconventional heating systems, not only in industrial activity, but also in households. Moreover, it is also experiencing a gradual departing from non-biodegradable packaging and products in favour of those biodegradable in a short period of time. These assumptions are relevant for work and the life of people and the need to make both more eco-friendly. This task applies to the activities of different scientific disciplines, including pedagogical and work studies, considering work in various aspects, on the basis of which they attempt to reveal expectations towards nature, the work itself and the people who are living and working in it.

Keywords: Environment, natural environment, human, work, pedagogy of work, work studies, awareness, environmental awareness (environmentally-friendly), raising the ecological (environmentally friendly) awareness

Barbara Baraniak - doktor habilitowana w zakresie pedagogiki - pedagogiki pracy, profesor Wydziału Nauk Pedagogicznych Uniwersytetu Kardynała Stefana Wyszyńskiego, autorka licznych publikacji, z których w tematykę artykułu wpisują się m.in.: Programy kształcenia zawodowego. Teoria, metodologia, aplikacje (2002), Edukacja w przygotowaniu człowieka do pracy zawodowej (2008), Metody badania pracy (2009), Wspótczesna pedagogika pracy z perspektywy edukacji, pracy i badań (2010 wyd. I; 2013 wyd. II), a także współautorka: Nowego stownika pedagogiki pracy (2001), Pedagogiki pracy (2007), monografii Poradnictwo zawodowe w kształtowaniu świadomości ekologicznej społeczeństwa. Od teorii do praktyki (2016) z rozdziałami: Teoria poradnictwa zawodowego w strukturze treściowej pedagogiki pracy - subdyscypliny naukowej wrażliwej na środowisko przyrodnicze oraz Gospodarka - zawody - praca - problemami wpisanymi w poradnictwo zawodowe promujące środowisko przyrodnicze. Adres do korespondencji: Wydział Nauk Pedagogicznych UKSW, ul. Wóycickiego 1/3, budynek nr 15, 01-938 Warszawa. Adres e-mail: b.baraniak@ uksw.edu.pl. 